\title{
Cortical astrocytes acutely exposed to the monomethylarsonous acid (MMA'") show increased pro-inflammatory cytokines gene expression that is consistent with APP and BACE-1 over-expression.
}

\author{
Escudero-Lourdes C., Uresti-Rivera EE., Oliva-González C., Torres-Ramos MA., Aguirre-Montes P., Gandolfi AJ. \\ Corresponding author: \\ Dr. Claudia Escudero Lourdes \\ Laboratorio de Inmunotoxicologia, CIEP. \\ Facultad de Ciencias Quimicas \\ Av. Dr. Manuel Nava \#6. Col. Universitaria \\ San Luis Potosí, S.L.P. \\ Mexico. \\ Phone (52) $4448262300 \times 6426$ \\ Fax (52) 4448262372 \\ Email: cescuder@uaslp.mx, clauescu@yahoo.com
}

\begin{abstract}
Long-term exposure to inorganic arsenic (iAs) through drinking water has been associated with cognitive impairment in children and adults; however, the related pathogenic mechanisms have not been completely described. Increased or chronic inflammation in the brain is linked to impaired cognition and neurodegeneration; iAs induces strong inflammatory responses in several cells, but this effect has been poorly evaluated in central nervous system (CNS) cells. Because astrocytes are the most abundant cells in the CNS and play a critical role in brain homeostasis, including regulation of the inflammatory response, any functional impairment in them can be deleterious for the brain. We propose that iAs could induce cognitive impairment through inflammatory response activation in astrocytes. In the

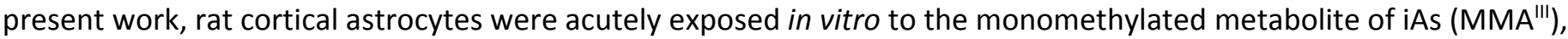
which accumulates in glial cells without compromising cell viability. MMA ${ }^{\prime \prime \prime} L_{50}$ in astrocytes was $10.52 \mu M$, however, exposure to sub-toxic MMA"I' concentrations (50 to $1000 \mathrm{nM}$ ) significantly increased IL-1 $\beta$, IL-6, TNF- $\alpha$, COX-2, and MIF-1 gene expression. These effects were consistent with amyloid precursor protein (APP) and $\beta$-secretase (BACE-1) increased gene expression, mainly for those MMA'II concentrations that also induced TNF- $\alpha$ over-expression. Other effects of $\mathrm{MMA}^{\mathrm{III}}$ on cortical astrocytes included increased proliferative and metabolic activity. All tested MMA ${ }^{\text {III }}$ concentrations

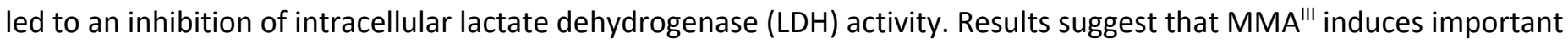
metabolic and functional changes in astrocytes that may affect brain homeostasis and that inflammation may play a major role in cognitive impairment-related pathogenicity in As-exposed populations.
\end{abstract}

Keywords. Astrocytes, arsenic, inflammation, cognitive, APP, BACE-1 


\section{Introduction}

Arsenic is a highly toxic metalloid widespread in nature and may occur as trivalent arsenite $\left(\mathrm{As}^{3+}\right)$ or pentavalent arsenate $\left(\mathrm{As}^{5+}\right)$. Inorganic compounds of As (iAs) are commonly present in underground water and, therefore, iAscontaining drinking water is the main human exposure source. Hydroarsenicism is a common health problem that threatens the health of millions of people around the world (IARC, 2012). Once iAs enters cells, it gets conjugated with glutathione and methylated by $A s^{\prime \prime \prime}$-methyl transferase (As3MT) in two consecutive stages, generating the highly toxic

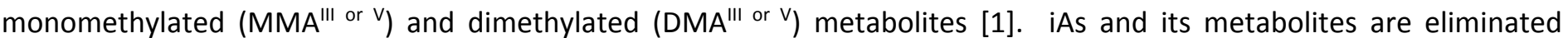
through urine and feces, but an important proportion of them will accumulate in different tissues, including the brain [2]. iAs and its metabolites accumulate in the cerebral cortex, hippocampus, striatum, midbrain, thalamus, pons, medulla oblongata, and pituitary gland of rodents intoxicated with $2.5,5$, and $10 \mathrm{mg} / \mathrm{kg} /$ day of sodium arsenite $[3,4]$.

Although several observations point out that human exposure to iAs may be associated with neurodegenerative diseases, epidemiological studies have failed to demonstrate a significant association. However, stronger evidence from exposed populations and experimental studies have linked iAs exposure with cognitive impairment [5-8]. In exposed populations, a decreased verbal IQ in a dose-response manner has been reported in children with high urinary As concentration [9], and cognitive impairment was also found in a study conducted with children exposed to low iAs levels $[10,11]$. In adult populations, a significant correlation between exposure to As and an impaired cognitive ability even at As concentrations below the EPA standards $(10 \mu \mathrm{g} / \mathrm{L})$ for drinking water has been reported also [12]. Even though these studies in exposed populations have some design limitations, results have contributed to propose that chronic exposure to iAs, at concentrations considered to be safe by the EPA and WHO, leads to cognitive impairment in exposed populations and could contribute to increase the risk for neurodegenerative diseases development later in life.

Studies evaluating hippocampal-dependent tasks in rodents have supported such observations. For example, in utero and early life exposure of rodents even to 50 or $100 \mu \mathrm{g} / \mu \mathrm{L}$ of iAs through drinking water leads to learning and memory deficits in adult offspring $[3,13]$. In another study, perinatal mice exposure to low iAs concentration $(55 \mu \mathrm{g} / \mathrm{L})$ led to reduced performance in forced swim test and increased response time in learned helplessness [10]. However the mechanisms underlying such neurotoxic effects that lead to As-associated cognitive dysfunction have not been completely elucidated.

In the clinical literature, It has been recognized that healthy individuals very often develop an important cognitive decline following an inflammatory challenge, such as an infection, surgery or head injury [14]. These observations suggest that any pro-inflammatory stimulus or agent that gains entry to the body through different routes could induce the same negative effect on human cognitive functions. In this sense, several reports have shown that acute or chronic exposure to iAs or its methylated metabolites lead to inflammatory responses activation in diverse cell types [15-17]; therefore, exposure to arsenicals may increase the risk for cognitive impairment through the induction of a sustained inflammatory response.

Although microglial cells, the resident macrophages in brain, have been extensively studied as main effectors of neuroinflammation-associated neurodegeneration, the role of astrocytes as contributors to cognitive impairment and neurodegenerative diseases pathophysiology is currently well recognized, because astrocytes, the most abundant glial 
cells, play an important role in maintaining the central nervous system's (CNS) physiology [18]. Additionally, astrocytes have been shown to be key regulators of the brain inflammatory response, releasing and responding to a variety of immune mediators including pro- (IL-6, TNF- $\alpha$ and GM-CSF) and anti-inflammatory (IFN- $\beta$ and TGF $\beta$ ) cytokines, and chemokines (CCL2, CCL5) [19].

One of the most characteristic pathologic features of neurodegenerative diseases and advanced cognitive deficits is the insoluble extracellular deposits of amyloid plaques, which are mainly composed of $\beta$-amyloid fibrils [20, 21]. Neurons are known to be major sources of $A \beta$ in the brain, however, astrocytes exceed several times the number of neurons and recent reports suggest that astrocytes produce and accumulate $A \beta$ and over-express the amyloid precursor protein (APP) cleaving enzyme, BACE-1 ( $\beta$-secretase) in response to chronic stress, promoting the pro-amyloidogenic pathway. Thus, even a small level of astrocytic $A \beta$ production could make a significant contribution to $A \beta$ production in neurological and neurodegenerative diseases. Moreover, activated astrocytes may increase $A \beta$ generation in neurons due to the release of inflammatory mediators [22, 23].

Based on these observations, our group proposes that As-induced neurotoxicity could involve its ability to activate oxidative and inflammatory responses in astrocytes and, in this way, could contribute to the pathophysiology of As-related cognitive deficit in As- exposed populations.

The aim of this study was to evaluate oxidative and inflammatory responses in rat cortical astrocytes acutely exposed to the monomethylated metabolite of As, $\mathrm{MMA}^{\prime \prime \prime}$, and to determine its association with cells activation and the expression of APP and BACE-1, whose increased expression is usually associated with cognitive impairment and neurodegeneration.

\section{Methods}

\section{Reagents}

Monomethylarsonous acid (MMA "'I ) was synthetized at the University of Arizona. Dulbecco's modified Eagle's medium (DMEM), phenol red-free DMEM, fetal bovine serum (FBS), and penicillin/streptomycin solution were obtained from GIBCO/Invitrogen. CellTiter $96^{\circledR}$ Aqueous Non-Radioactive Cell Proliferation Assay was purchased from PROMEGA (Fitchburg, WI, USA). Cytotoxicity detection kit (LDH) was obtained from ROCHE (Indianapolis, IN. USA). Reagents for nitrite assay (Griess reaction), LPS (from Escherichia coli), and poly-D-lysine were purchased from Sigma Chemical Co. (St. Louis, MO).

\section{Astrocyte primary cultures}

Primary cortical astrocyte cultures were obtained through a modified method previously described [24]. All procedures described in this manuscript were carried out in accordance to the Guide for the Care and Use of Laboratory Animals by the Universidad Autónoma de San Luis Potosí (UASLP). Briefly, complete brains were isolated from newborn (up to 1day-old) Wistar rats and placed in an ice-cold Hanks' balanced salt solution (HBSS) without $\mathrm{Ca}^{2+}$ or $\mathrm{Mg}^{2+}$, the cortices were then peeled and the hippocampus and meninges from each individual cortex were carefully removed and discarded. The cleaned cortices were mechanically dissociated by sequential passage through a $1 \mathrm{~mL}$ pipette, $5 \mathrm{~mL}$ and 1 
$\mathrm{mL}$ syringes, respectively, the sediment was suspended and cultured in $75 \mathrm{~cm}^{2}$ tissue culture flasks pre-coated with polyD-lysine with DMEM containing $10 \%$ fetal bovine serum and $100 \mathrm{U} / \mathrm{mL}$ penicillin and $100 \mu \mathrm{g} / \mathrm{mL}$ streptomycin. The cultures were maintained at $37^{\circ} \mathrm{C}$ with $5 \% \mathrm{CO}_{2}$ in a $100 \%$ humidified atmosphere. The medium was changed every 3 days. When cells grew to confluence (approximately 7-10 days), flasks were shaken overnight (170 rpm at $37^{\circ} \mathrm{C}$ ) to get rid of microglia and oligodendrocytes. After shaking, the medium was removed and the astrocytes were washed 3 times with ice-cold PBS solution and lifted by trypsinization and re-plated at different densities depending on the experiment to be performed. The purity of the primary culture of astrocytes was determined by immunocytochemistry with antibodies against glial fibrillary acidic protein (GFAP). A > 95\% purity was considered adequate.

\section{GFAP -Immunofluorescence staining}

Immunostaining for GFAP was used for astrocytes culture characterization. Cells were cultured in PDLtreated 12-mm glass cover-slips placed at the bottom of a 12-well plate ( $3 \times 10^{4}$ cells/well) and left to attach for $3 \mathrm{~h} ; 1$ $\mathrm{mL}$ of complete DMEM was added to each well and incubated overnight. Cells were then washed with PBS, fixed in $4 \%$ paraformaldehyde for $20 \mathrm{~min}$, permeabilized with methanol at $-20{ }^{\circ} \mathrm{C}$ for $10 \mathrm{~min}$, and pre-incubated with $2 \%$ bovine albumin in PBS for $1 \mathrm{~h}$. Fixed cells were incubated overnight at $4{ }^{\circ} \mathrm{C}$ with the primary antibody (rabbit anti-GFAP, 1:200 dilution, Sigma Chemical Co.) followed by a $1 \mathrm{~h}$ incubation with Alexa 488-conjugated goat anti-rabbit secondary antibody, 1:200 dilution (Molecular Probes, Eugene, OR, USA). The cell nucleus was counter-stained with 4'6,diamidino-2-phenylindole dihydrochloride (DAPI) and observed with a fluorescence microscope.

\section{Cytotoxicity assay, $L D_{50}$}

To determine lethal MMA ${ }^{I I I}$ concentrations, toxicity assays and $\mathrm{LD}_{50}$ were conducted in primary cortical astrocytes. Astrocytes, $8 \times 10^{3}$ cells/well, were treated with $0,50,125,250,500,1250,2500,5000,10,000$, and 15,000 nM MMA ${ }^{\prime \prime \prime}$, for 24 and $48 \mathrm{~h}$ in phenol red-free DMEM containing $2 \%$ fetal bovine serum and $100 \mathrm{U} / \mathrm{mL}$ penicillin and $100 \mathrm{\mu g} / \mathrm{mL}$ streptomycin. Cytotoxicity was estimated using a commercial system (Cytotox $96^{\circledR}$ nonradioactive cytotoxicity assay, PROMEGA), which determines lactate dehydrogenase enzyme (LDH) activity, according to the provider's guidelines. This is a colorimetric assay that measures the enzymatic conversion of lactate to pyruvate exerted by $L D H$, which is released to the medium from damaged cells. The enzymatic activity in culture supernatants is determined by the NADH-mediated conversion of a tetrazolium salt into a red formazan product. The color intensity is proportional to the number of lysed cells and can be determined spectrophotometrically, recording absorbance (Abs) at $490 \mathrm{~nm}$. Supernatants from lysed cells obtained by the use of a lysis buffer provided by the manufacturer were used as positive control (100\% of LDH activity or cellular toxicity). Cellular toxicity was calculated as a percentage of control (percent cytotoxicity $=100 \times\left[\right.$ Experimental LDH release $(O D 490) /$ Maximum LDH release (OD490)]). $\mathrm{LD}_{50}$ was calculated from these data using linear regression. In this work, results are presented as cellular viability, which was determined by subtracting cellular toxicity data from non-exposed cells data, which were considered to be as $100 \%$ viability. 
In a different group of experiments, cells were incubated with 25 to $5000 \mathrm{nM} \mathrm{MMA}$ "II for 24 or $48 \mathrm{~h}$. In one set of cultures, the medium was removed and cells were lysed after 24 or $48 \mathrm{~h}$ exposure with the lysis buffer provided by the assay kit's manufacturer. In another set of cellular cultures, supernatants were recovered after 24 or $48 \mathrm{~h}$ exposure. LDH activity was measured in supernatants and in cellular lysates, as described before. Cells without exposure to MMA ${ }^{\prime \prime \prime}$ were included as control. These results are presented as LDH activity as a function of the MMA"I concentration to which the astrocytes were exposed.

\section{Morphological changes}

To determine whether MMA ${ }^{\prime \prime \prime}$ induces morphological changes associated with astrocytes activation due oxidative or inflammatory responses, $1.5 \times 10^{4}$ cells/well were seeded in 12 well-flat-bottom culture plates; $24 \mathrm{~h}$ later, the medium was replaced by fresh supplemented DMEM medium containing 50, 250, 500, 1000 nM MMA '"'. Morphological changes were recorded in each well after 24 and $48 \mathrm{~h}$ with the use of a Nikon ECLIPSE TS100 inverted phase-contrast microscope; images were taken and processed with the use of the Q Capture Pro-7 digital camera system. Each MMA"l' concentration was evaluated for morphological changes induction in triplicate and at least three different images per well were taken.

\section{ROS production}

Arsenic has been well demonstrated to induce oxidative stress, as its main toxicity mechanism. Reactive oxygen species (ROS) production was evaluated in astrocytes exposed to 25, 50, 125, 250, 500 and $1000 \mathrm{nM} \mathrm{MMA}^{\mathrm{III}}$ through a previously reported method [25]. Astrocytes were cultured in a black walled 96 -well plate, $8 \times 10^{3}$ cells/well were allowed to settle for $24 \mathrm{~h}$ before conducting the assays. The medium was removed from the wells and replaced with phenol red-free $10 \%$ serum-supplemented DMEM; $100 \mu \mathrm{L}$ of the different MMA ${ }^{\text {III }}$ concentrations were added to the

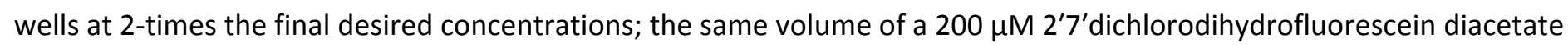
(DCFH-DA) solution was added to each well. Cells exposed to $10 \mu \mathrm{M}$ sodium nitroprusside (SNP) were used as positive control. ROS production was evaluated as fluorescence intensity in a fluorospectrophotometer at 488-nm excitation and 525-nm emission wavelengths. Fluorescence intensity was measured every 5 min the first hour and at 2, 4, and $6 \mathrm{~h}$ after MMA "I had been added to the culture.

\section{Nitric Oxide (NO) production assay}

Accumulation of nitrite as a result of the oxidation of produced NO was measured by the Griess reaction in MMA'I'-exposed astrocytes. Cells were seeded on 96-well, flat bottom, culture plates and incubated for $24 \mathrm{~h}$. The medium was discarded and replaced with phenol red-free DMEM containing $2 \%$ fetal bovine serum and $100 \mathrm{U} / \mathrm{mL}$ penicillin and $100 \mathrm{\mu g} / \mathrm{mL}$ streptomycin containing 0, 25, 50, 125, 250, 500 and $1000 \mathrm{nM} \mathrm{MMA} \mathrm{I'I.} \mathrm{Sodium} \mathrm{nitroprusside}$ $(10 \mathrm{mM})$ was included as a positive control for NO release. Astrocytes were allowed to grow for 24 additional hours in 
presence of the toxicant. After the incubation, $100 \mu \mathrm{L}$ of the supernatant were mixed with the same volume of Griess reagent [0.1\% N-(1-naphthyl) ethylenediamine dihydrochloride in deionized water and $2 \%$ sulfanilamide in $0.5 \mathrm{M} \mathrm{HCl}]$. The absorption at $540 \mathrm{~nm}$ with a reference wavelength at $620 \mathrm{~nm}$ was recorded with a microplate reader (Multiskan, LabSystems, Beverly, MA. USA). Total nitrite concentration in samples was determined from a $\mathrm{NaNO}_{2}$ standard curve. 


\section{Proliferation assay}

Proliferation assay was based on the measurement of 5-bromo-2-deoxyuridine (BrdU) incorporation during DNA synthesis through the use of a commercial ELISA-based system. The assay was conducted according to the provider's protocol (Cell proliferation ELISA BrdU, Roche, USA). Briefly, cells were incubated with the desired MMA"II concentration for 24 and $48 \mathrm{~h}$. BrdU labeling solution was added to the cultures at least $8 \mathrm{~h}$ before the ELISA assay was performed. The culture medium was removed, cells were fixed, and DNA was denatured. Afterwards, cells were incubated with antiBrdU-POD solution for $90 \mathrm{~min}$, and antibody conjugates were removed in three washing cycles. Immune complexes were detected by means of TMB substrate for $15 \mathrm{~min}$ and quantified by measuring the absorbance at $450 \mathrm{~nm}$ and $690 \mathrm{~nm}$. Proliferation assay was conducted in duplicate with triplicates of each condition.

\section{MTS -based metabolic assay}

Astrocytes were seeded in 96-well, flat-bottom, plates at a density of $8 \times 103$ cells/well for $24 \mathrm{~h}$, then, exposed to $0,50,250,500$ and $1000 \mathrm{nM} \mathrm{MMA}$ "II and allowed to grow for 24 additional hours. Following the arsenic treatment, cells metabolic activity was measured using the MTS-based CellTiter 96-cell assay (PROMEGA), according to manufacturer's recommendations. MTS [3-(4,5-dimethylthiazol-2-yl)-5-(carboxymethoxyphenyl)-2-(4-sulfophenyl)-2Htetrazolium] reduction technique evaluates intracellular NADH-dependent dehydrogenase activity in viable cells.

\section{Cytokines, APP and BACE-1 gene expression assays}

After isolation from rats brain cortex, cortical astrocytes were cultured in $75 \mathrm{~mm}$ Petri dishes, left to settle for 24 $\mathrm{h}$ in supplemented DMEM, and then exposed to 25,50, 125, 250, 500 and 1000 nM MMA ${ }^{\prime \prime \prime}$ in triplicate for 6 h. Total RNA was isolated from each plate using the Trizol ${ }^{\circ}$ reagent (Invitrogen, Life Technologies, Waltham, MA, USA) according to the manufacturer's protocol. cDNA synthesis was performed using SuperScript II Reverse Transcriptase (Invitrogen, Life Technologies), following the manufacturer's recommendations. Real time PCR was carried out in 96-well reaction plates using the super Syber mix (ROCHE) with specific primers in a 10- $\mu \mathrm{L}$ final volume reaction. The PCR was conducted in an ABI 7500 detection system (Applied Biosystems, Foster City, CA, USA) with the following cycling conditions: $95^{\circ} \mathrm{C}$ for 10 $\min$ (initial denaturation), 40 cycles of $95^{\circ} \mathrm{C}$ for $15 \mathrm{~s}$, and $60^{\circ} \mathrm{C}$ for $60 \mathrm{~s}$ for annealing and extension. Amplification of the target cDNA was normalized to $\beta$-actin expression. Relative mRNA expression levels of each gene were calculated using the 2- ${ }^{\Delta \Delta C T}$ method. Primers for interleukin 1-beta ( IL-1ß), interleukin 6 (IL-6), tumor necrosis factor alpha (TNF- $\alpha$ ), macrophage inhibitory factor (MIF), cyclooxigenase 2 (COX2), amyloid precursor protein (APP), and BACE-1 are listed in Table 1. 


\section{Statistical analysis}

At least three independent experiments using primary astrocyte cultures pooled from 1-3 cortices for each experiment were analyzed. Statistical significance was determined by one or two-way ANOVA with Newman-Keuls or Tukey post-test, correspondingly, using the Graph Pad Prism version 5.01 software for Windows, Graph Pad Software (San Diego, CA, USA). Data are presented as the mean ( \pm standard deviation, SD) and $p<0.05$ was considered significant.

\section{Results}

Cellular characterization through GFAP-immunostaining showed that cultures were composed of around $98 \%$ astrocytes (Figure 1).

\section{Cytotoxicity assays}

To determine the toxic effects of different $\mathrm{MMA}^{\text {III }}$ concentrations on astrocytes, cell viability and cell membrane integrity, as well as morphological changes, were evaluated.

At concentrations of 50 to $2500 \mathrm{nM}(5 \mu \mathrm{M}), \mathrm{MMA}^{\text {III }}$ did not lead to any cell toxicity signs on the rat cortical astrocytes after $24 \mathrm{~h}$ exposure in terms of morphological changes. However, at higher concentrations astrocytes started to lose their classical shape and became detached from plates when compared to non-treated cells. The most significant $\mathrm{MMA}^{\mathrm{III}}$-mediated toxic effect was observed in cells treated with 15,000 nM of MMA"I', which led cells to detach from the flask and they appeared severely damaged (Figure 2).

The effect of MMA"I on membrane integrity after $24 \mathrm{~h}$ exposure was evaluated through LDH release. As shown in Figure 3, treatment with $\mathrm{MMA}^{\mathrm{III}}$ resulted in increased LDH release only in astrocytes treated with 10,000 nM and higher $\mathrm{MMA}^{\mathrm{III}}$ concentrations, compared with non-treated cultures. Exposure to 25 and up to $5000 \mathrm{nM} \mathrm{MMA}$ "II had no significant effect on LDH release in astrocytes at 24 or $48 \mathrm{~h}$ after treatment. From these results, the LD $_{50}$ was calculated to be $10,522 \mathrm{nM}(10.52 \mu \mathrm{M}) \mathrm{MMA}^{\text {III }}$ for rat primary cortical astrocytes. Concentrations below $1000 \mathrm{nM} \mathrm{MMA}^{\text {III }}$ were used to evaluate inflammatory and oxidative responses elicited by this toxicant in primary astrocytes.

As can be noticed in Figure 3, in our hands, LDH activity from supernatants of astrocytes exposed to 25 to 1000 nM MMA ${ }^{\prime \prime \prime}$ for $24 \mathrm{~h}$ showed a trend to decrease compared to non-exposed cells. It is important to point out that there is always some remnant LDH activity in the cell culture medium due to supplementation with $2 \%$ SBF; therefore, even supernatants from healthy non-exposed cells show some background LDH activity. However, absorbance data obtained of supernatants from astrocytes exposed to non-toxic concentrations were consistently lower than control, suggesting that MMA ${ }^{\text {III }}$ could be affecting LDH activity. Therefore, in a different set of experiments, intracellular LDH activity was measured to determine the effect of $\mathrm{MMA}^{\text {III }}$ on this enzyme in astrocytic cultures. To do this, cells were incubated with 25 to $5000 \mathrm{nM} \mathrm{MMA}^{\mathrm{III}}$ for 24 or $48 \mathrm{~h}$. Then, in one set of cells the culture medium was removed and cells were lysed after 24 or $48 \mathrm{~h}$ exposure with the buffer provided by the LDH kit's manufacturer and lysates were collected. In another set of cellular cultures, supernatants were recovered after 24 or $48 \mathrm{~h}$ exposure. LDH activity in supernatants and in cellular lysates was measured as described before. Cells without exposure to MMA"I were included as control. In this 
case, results were presented as LDH activity as a function of the MMA ${ }^{\text {III }}$ concentration to which the astrocytes had been exposed.

As seen before, supernatants from astrocytes exposed for 24 or $48 \mathrm{~h}$ to 50 to $1000 \mathrm{nM} \mathrm{MMA}$ "ll showed a decreased LDH activity, determined in terms of absorbance due to formazan formation, compared with non-exposed cells, mainly after $48 \mathrm{~h}$ exposure (Figure $4 \mathrm{~A}$ ). On the other hand, intracellular LDH activity was significantly decreased (up to 70\%) in astrocytes treated with any of the MMA'II assayed concentrations (Figure 4B).

One possible explanation for this observation is that at low non-cytotoxic MMA ${ }^{\text {III }}$ concentrations, the LDH activity of the serum-containing medium is inhibited by the $\mathrm{MMA}^{\text {III }}$ added to the medium where the cells were grown; however, higher MMA"I concentrations are toxic for astrocytes inducing their lysis and, therefore, releasing a high LDH amount to the medium that can be detected in supernatants. However, for the intracellular LDH determination in astrocytes, after 24 or $48 \mathrm{~h}$ exposure to 50 to $5000 \mathrm{MMA}^{\prime \prime \prime}$, the latter has entered the cells and inhibited LDH activity at these non-lethal concentrations. These results suggest that LDH is a direct target for MMA ${ }^{\prime \prime \prime}$ in rat cortical astrocytes. 
Exposure to low nanomolar MMA ${ }^{\prime \prime \prime}$ concentrations induced ROS production

Oxidative stress is a quick response that is very often elicited after the cells are exposed to different toxic substances. In this work, cortical astrocytes were exposed to MMA ${ }^{\prime \prime \prime}$ in concentrations ranging from 25 to $1000 \mathrm{nM}$ and assayed for ROS production. Results showed that only those astrocyte cultures that were exposed to 25 and $50 \mathrm{nM}$ $M_{M A}$ "II had a strong oxidative response as soon as $3 \mathrm{~min}$ after the toxicant had been added to the cells. Based on the oxidation of DAFH-related fluorescence, it was calculated that around 70\% more ROS was produced after only 3 min in cells exposed to $50 \mathrm{nM} \mathrm{MMA}^{\text {III }}$ when compared to non-exposed cells. ROS production duplicated after 55 min and peaked at $6 \mathrm{~h}$ post-exposure to $50 \mathrm{nM}$ and at $24 \mathrm{~h}$ post-exposure to $25 \mathrm{nM}$. Interestingly, exposure to higher concentrations did not increase ROS as compared to untreated cells. Therefore, in our conditions, oxidative stress induction by MMA'l' did not follow a dose-dependent behavior (Figure 5).

On the other hand, we found no significant differences in NO production after exposure to MMA ${ }^{\text {III }}$ when compared to non-treated cells (data not shown), suggesting that MMA"I did not induce nitrosative stress in rat cortical astrocytes at the assayed $\mathrm{MMA}^{\mathrm{II}}$ concentrations

\section{Exposure to $M M A^{\prime \prime \prime}$ increased BrdU incorporation in cortical astrocytes}

The intracellular oxidative stress, as well as inflammatory cytokines, is known to induce activation of several intracellular pathways including those related with cell survival and proliferation. Astrocytes that were exposed for 24 or $48 \mathrm{~h}$ to 25 to $1000 \mathrm{nM} \mathrm{MMA}$ "II were also assayed for proliferation induction after 24 and $48 \mathrm{~h}$ through the BrdU incorporation assay. Results showed that all assayed concentrations led the cortical astrocytes to incorporate more BrdU to DNA in presence of $\mathrm{MMA}^{\text {III }}$ in a dose-response fashion. This result could be interpreted as increased cellular proliferation; however it could also be the result of an increased As-induced damage/repair process as previously reported [26]. This effect was apparently independent from the oxidative intracellular state, but it seems to agree with the IL-6 over-expression found at all assessed MMA'"' concentrations (Figure 6).

\section{Astrocytes showed increased metabolic activity after exposure to $M M A^{\prime \prime \prime}$}

Astrocytes mainly rely on anaerobic oxidative phosphorylation to get energy, for this reason aerobic metabolism, which is mediated by mitochondria, is weaker in these cells when compared to neurons that use glycolysis for ATP production. However under stressful conditions, astrocytes increase aerobic metabolism to overcome the energy need [27]. MMA"I' -effect on astrocytes metabolism was assayed through the MTS transformation assay, which mainly evaluates aerobic mitochondrial activity. Reduction of MTS is mediated by NADH or NADPH inside and out of mitochondria [28] and this assay's results can be used to measure changes in cellular metabolism. Results show a significant increase of up to $28.3 \%$ in the ability to reduce MTS in cells exposed to 25, 50, 125 and 250 nM MMA"I when compared to non-exposed cells (Figure 7). 
MMA II' increased pro-inflammatory cytokine gene expression in astrocytes

We investigated whether $\mathrm{MMA}^{\text {III }}$ is able to induce pro-inflammatory genes transcription in cortical astrocytes. Astrocytes were exposed for $6 \mathrm{~h}$ to sub-toxic concentrations of $\operatorname{MMA}^{\prime \prime \prime}(50,250,500$ and $1000 \mathrm{nM})$. Consistent with ROS over-expression, $50 \mathrm{nM} M \mathrm{MM}^{\text {III }}$ induced the most significant changes in the expression of genes coding for IL-1 $\beta$, IL-6, TNF- $\alpha$, MIF, and COX-2; the COX-2 transcript was the one to show the biggest change at this MMA ${ }^{\text {III }}$ concentration (up to 29.9\%). The same genes were found over-expressed in cells exposed to $125 \mathrm{nM} \mathrm{MMA}$ "ll although the changes were not as impressive as with $50 \mathrm{nM}$. Cells exposed to $500 \mathrm{nM} \mathrm{MMA}^{\text {III }}$ showed an over-regulation of three pro-inflammatory genes, IL-1- $\beta$, IL-6, and TNF- $\alpha$, whereas IL- 6 was the only gene over-expressed in cells exposed to 125 and 1000 nM MMA"II (Figure 8). These results show that As-induced inflammatory response neither follows a dose-response behavior in rat cortical astrocytes; rather the most relevant changes seem to depend on the intracellular oxidative state.

\section{$M M^{\prime \prime \prime}$ induced APP and BACE-1 gene over-expression in astrocytes}

Reactive astrocytes are implicated in amyloid plaques formation due to the fact that inflammatory responses induce BACE-1 increased expression, leading to an increased APP processing through the amyloidogenic pathway [23]. Importantly, as is discussed later on, $A \beta$ oligomers accumulation in the synaptic cleft induces memory and learning impairment [29]. Therefore, we examined the effect of acute exposure to MMA ${ }^{\text {III }}$ on the expression of genes encoding for the amyloid precursor protein (APP), as well as of the gene encoding for $\beta$-secretase (BACE-1), which is implicated in $A \beta$ formation. As shown in Figure 9, APP gene expression showed a significant increase in astrocytes after exposure to 50, 125 and $500 \mathrm{nM} \mathrm{MMA} \mathrm{"',} \mathrm{which} \mathrm{was} \mathrm{also} \mathrm{consistent} \mathrm{with} \mathrm{an} \mathrm{increased} \mathrm{BACE-1} \mathrm{gene} \mathrm{expression.} \mathrm{These} \mathrm{concentrations}$ were shown to induce IL-1 $\beta$, IL-6, and TNF- $\alpha$ over-regulation in astrocytes, suggesting that these cytokines could be associated to the observed increase in APP and BACE-1 expression. 


\section{Discussion}

iAs and its metabolites-related toxicity has been extensively studied elsewhere in vitro or through the use of different animal models. Specifically, some of the mechanisms that have been described could be involved in the cognitive deficit that has been observed in children and adults exposed to As-contaminated water, as well as in experimental models, including: i) impaired monoaminergic [30, 31], glutamatergic [32] and cholinergic [33] signaling; ii) increased APP expression and B amyloid formation [34], iii) impaired synaptic transmission [35], increased tau protein phosphorylation [36, 37], and reticulum endoplasmic stress induction [38].

All these As-induced neurotoxicity mechanisms are related directly or indirectly to inflammatory responses impairment [39]. In this regard, microglial cells have been extensively studied as the primary effectors of inflammatory responses in the central nervous system after a brain aggression; however, various reports have shown that astrocytes, the most abundant glial cells that contribute to the blood brain barrier architecture and function, are the first cells to respond to a toxic challenge and induce microglia recruitment through different chemokines production [40, 41]. Impaired astrocytes' functioning has been associated with neurological disorders, such as Alzheimer and Parkinson disease $[22,42]$. However, there is scarce information in the formal literature exploring the As-induced inflammatory response and its consequences on astrocytes.

As described by Koehler et al. [43], astrocytes are able to reduce intracellularly arsenate to arsenite, to keep it in a reduced state and to metabolize it through methylation to form MMA and DMA. In Bergman cells, a special type of radial glial cells, $\mathrm{MMA}^{\mathrm{III}}$ is produced and accumulated up to $1.2 \mathrm{ng} / \mathrm{mg}$ protein after a single in vitro exposure to $1.5 \mu \mathrm{M}$ iAs without compromising cells viability. In such glial cells, MMA ${ }^{\text {III }}$ accounted for $60 \%$ of total intracellular As, representing the main accumulated As species after $24 \mathrm{~h}$ exposure to arsenite [44]. Based on these observations and because $\mathrm{MMA}^{\text {III }}$ has been demonstrated to impair a variety of cellular functions, including those related to proliferation, oxidative stress, and inflammation; in this work, rat cortical astrocytes were exposed in vitro to nanomolar concentrations of this metabolite to determine their effect on oxidative and inflammatory responses.

In our experimental conditions, LDH and MTS-based toxicity assays showed that rat cortical primary astrocytes were highly resistant to $\mathrm{MMA}^{\mathrm{III}}\left(\mathrm{LD}_{50}=10.5 \mu \mathrm{M}\right)$, which is consistent with previous studies showing that astrocytes are able to resist high arsenite concentrations; those studies show that astrocytes viability gets compromised at concentrations ranging from $200 \mu \mathrm{M}$ to $1.0 \mathrm{mM}$ after $24 \mathrm{~h}$ in vitro incubation with this toxicant $[43,45,46]$.

In this sense, it is relevant to point out that astrocytes play a critical role in iron and copper homeostasis, being able to introduce and accumulate these metal ions in high concentrations without compromising viability [47, 48]. It is possible that astrocytes are able to handle such high arsenic concentrations through these or similar mechanisms.

Astrocytes are also known to play a critical role in the defense against oxidative stress and toxins since they express high glutathione concentrations and show elevated glutathione peroxidase and glutathione reductase activity. Additionally astrocytes express high concentrations of enzymes that supply the required NADPH for reduction reactions [49]. In the present work, astrocytes acutely exposed to 25 and $50 \mathrm{nM} \mathrm{MMA}$ "II showed a strong oxidative response in the first few minutes after exposure, which remained high after $6 \mathrm{~h}$ for $50 \mathrm{nM} \mathrm{MMA}$ "II and after $24 \mathrm{~h}$ for cells exposed to 25 
nM MMA ${ }^{\prime \prime \prime}$, whereas higher concentrations failed to induce oxidative stress, even at micromolar concentrations. Previous works have demonstrated that after exposure to high micromolar arsenite concentrations (1.5 to $10 \mu \mathrm{M}$ iAs) astrocytes do not show oxidative stress, due to the increased superoxide dismutase 1 (SOD 1) expression, however, with such iAs concentrations several intracellular pathways were impaired and DNA damage was observed [44, 50]. In this work, we cannot explain why only low MMA $\mathrm{MMI}^{\mathrm{II}}(25$ and $50 \mathrm{nM})$ concentrations induced cellular oxidative stress, and higher concentrations did not, but it is possible that the protective anti-oxidant mechanisms in cortical astrocytes are triggered only once a threshold of toxic levels of intracellular ROS production has been reached.

In the brain, after a trauma, astrocytes and other glial cells get activated and proliferate causing sustained inflammatory processes, which trigger the release of several neurotoxic molecules, such as ROS, nitric oxide, and more pro-inflammatory cytokines, such as IL-1, IL-6, TNF- $\alpha$, IFN- - . These molecules have been related to neuronal harm and are proposed to be involved in the generation or progression of neurodegenerative diseases, such as AD [19]. In this sense, it is well known that iAs and its methylated metabolites induce in vivo as well as in vitro inflammatory responses that, in turn, activate different signaling pathways associated with inflammation, proliferation, and cell survival [16, 5156].

Our group has previously demonstrated that in vitro exposure to MMA"I at concentrations as low as $50 \mathrm{nM}$ leads to the activation of different signaling pathways and transcription factors associated with cell proliferation survival and inflammatory responses activation, including NFK $\beta, A P-1 / c-J u n, E R K 1 / 2$, and AKT in a model of immortalized human urothelial cells [16]. Here, we demonstrated that different sub-toxic nanomolar concentrations of MMA ${ }^{\text {III }}$ induce rat cortical astrocytes to over-regulate pro-inflammatory cytokines expression in a dose-response manner. Interestingly, bigger changes in IL-1 $\beta$, IL-6, TNF- $\alpha$, MIF, and COX-2 were observed in cells exposed to low MMA"I' concentrations (50 $\mathrm{nM}$ ), the same concentration that previously showed to induce oxidative stress in treated astrocytes in this study, whereas higher concentrations led to less impressive changes.

These results suggest that $\mathrm{MMA}^{\mathrm{II}}$ induces activation of inflammatory and proliferative responses through a mechanism that seems to be independent of the intracellular oxidative state and without compromising astrocyte viability, but increasing cells proliferation and metabolism. However, oxidative stress seems to contribute to MMA ${ }^{\text {III- }}$ induced pro-inflammatory responses in astrocytes exposed to low MMA ${ }^{\text {III }}$ concentrations.

Up to this point, we demonstrated that $\mathrm{MMA}^{\text {III }}$ is able to induce astrocytes-mediated inflammatory cytokines over-expression, which correlates with increased cellular proliferation and metabolic activity. This pro-inflammatory environment, generated by MMA "II in astrocytes, could contribute to the development of cognitive impairment in exposed populations.

It is important to remember that amyloid plaques, formed by insoluble protein fibrils, are associated with human cognitive decline and neurodegeneration. These fibrils are formed of $A \beta$ derived from the proteolytic cleavage of the amyloid precursor protein (APP) [57], however soluble $A \beta$ oligomers (ABOs), which are not detected through regular tissue staining techniques, have been demonstrated to be the neurotoxic form of $A \beta[29,58]$.

A pro-inflammatory environment is known to be the cause of BACE-1( $\beta$ secretase) over-regulation, leading to the formation of ABOs [59]. In mouse, the levels of APP are increased in pro-inflammatory conditions [60]. Moreover, 
Zhao et al., 2011[23], demonstrated that pro-inflammatory cytokine combinations, like TNF- $\alpha$ plus IFN- $\gamma$, synergistically increase levels of endogenous APP and BACE1 in astrocytes, as compared to individual cytokines alone. On the other hand, As is reported to affect expression and processing of APP in neuronal cells $[34,61]$. Therefore, the connecting factor between arsenic-induced neurotoxicity and $A \beta O$ s formation is very likely to be the As-induced inflammatory responses.

Importantly, several reports suggest that astrocytes are also able to produce and accumulate $A \beta$ through the increase in BACE-1 ( $\beta$-secretase) expression $[22,23]$, therefore contributing to neurodegeneration.

In agreement with this observation, our results showed an increased APP and BACE-1 gene expression mainly after astrocytes were exposed to 50, 125 and $500 \mathrm{nM} \mathrm{MMA}^{\prime \prime \prime}$, the same MMA ${ }^{\prime \prime \prime}$ concentrations that showed a more significant induction of IL-1b, IL-6 and TNF- $\alpha$ gene expression, suggesting that these cytokines could play a critical role in astrocyte-mediated $\mathrm{AB}$ production.

It is well known that Inflammation plays a key role in the onset and progression of sporadic AD [14]. The mechanisms involve astrocytes and microglia activation, which over-express IL-1, promoting APP translation through an IL-responsive element located in the 5'-untranslated region (5'-UTR) of APP mRNA [62].

Recently, Ashok [63] demonstrated that oxidative stress and inflammation induced by As, in rats exposed from 05 days of gestation and up to 180 days postnatal, lead to an enhanced APP expression that is further processed by the enzymes BACE1 and presenilin (PS), leading to an A $\beta$ over-production. Furthermore, at 90 days post-natal exposure, animals showed a significant cognitive impairment. IL1- $\beta$ over-regulation was found in association with increased APP protein expression in these animals. Authors demonstrated that the corresponding mechanism involved the interleukinresponsive region located at the 5'-untranslated region (5'-UTR) of APP mRNA previously described [62].

Based on our results and former observations, we hypothesize that MMA'I', which is produced and accumulated by astrocytes, induces APP increased gene expression as a result of increased IL-1b, IL-6, and TNF- $\alpha$ gene expression. In turn, IL-1 $\beta$ binds to APP mRNA positively modulating its translation in ribosomes. On the other hand, MMA'"-induced BACE-1 over expression increases APP processing towards the amyloidogenic pathway leading to AßOs formation.

One of the mechanisms that has been described through which $A \beta$ contributes to cognitive impairment and neurodegeneration involves neuronal ionotropic receptors, AMPA- and NMDA-type, and the metabotropic glutamate receptor, mGluR5, implicated in memory formation, which are targeted by ABOs. Accordingly, increased $A \beta O$ s levels or the injection of $A B O s$ in rodent's brains are known to impair synaptic plasticity by inhibiting long term potentiation (LTP) [29].

On the other hand, as described in the results section, concentrations ranging from 25 to $5000 \mathrm{nM} \mathrm{MMA}^{\text {III led to }}$ a significant decrease in intracellular LDH activity, which was measured through the conversion of lactate to pyruvate based on the LDH activity determination commercial system. As known, astrocytes provide neurons with lactate that is used as their main ATP source by them and is essential for long term memory formation (LTM) [27]. Therefore, LDH inhibition may impair the lactate shuttle between astrocytes and neurons, compromising neuronal energy metabolism and having effect on LTM. We consider this a very interesting topic that needs further investigation. 
Another interesting finding of the present study was the significant increased aerobic metabolic activity of astrocytes after exposure to 25, 50, 125 and $250 \mathrm{nM} \mathrm{MMA}{ }^{\prime \prime \prime}$, which seems to be consistent with the most important changes observed in pro-inflammatory genes expression. In this sense, it has been proposed that inflammatory responses and increased mitochondrial aerobic metabolism are interconnected in astrocytes. It has been found that the inflammatory cytokines IL-1and TNF- $\alpha$ stimulate astrocytic oxidative mitochondrial metabolism, leading to a decreased lactate supply to neurons [64]. In this way, arsenic may also compromise neurons' energetic metabolism through the activation of astrocytic inflammatory responses.

As a whole, observations of this exploratory study suggest that As could lead to memory impairment and possibly to neurodegeneration through the activation of oxidative and inflammatory responses, which in turn increase $A \beta$ formation through APP and BACE-1 over-regulation in astrocytes. These results also suggest that exposure to arsenic may induce important metabolic and functional changes in astrocytes that have a negative impact on brain homeostasis. In summary, we consider these results as relevant general evidence on the role of astrocytes in the pathogenicity of cognitive impairment and neurodegeneration in As-exposed populations; further studies should be done in this direction.

\section{Acknowledgments}

The present study was partially supported by Fondo de Apoyo a la Investigacion (FAI), UASLP. No. C14-FAI-04-10.10.

\section{Conflict of interest.}

Authors declare to have not conflict of interest.

\section{Figure legends}

Figure 1. Astrocytes culture characterization. Primary rat cortical astrocytes cultures were characterized through immunostaining against glial fibrillary acidic protein (GFAP). After removing microglial cells from cultures through agitation, cell cultures were constituted by $95 \%$ astrocytes. Green staining corresponds to anti-GFAP labeled astrocytes whereas blue staining corresponds to DAPI dye, which identifies the cellular nuclei.

Figure 2. Morphological examination. Astrocytes were exposed to 50 to 15,000 nM MMA'II. Morphological changes were analyzed under the microscope and recorded with a digital camera. Representative images are shown. Cells did

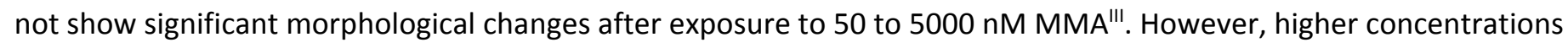
induced cells to detach from the flask, showing a rounded morphology.

Figure 3. Cytotoxicity assays. A) Rat cortical astrocytes were cultured with increasing MMA ${ }^{\text {III }}$ concentrations. Supernatants were assayed for cellular LDH release after 24 or $48 \mathrm{~h}$ exposure. B) Cellular toxicity based on LDH release. Asterisks denote significant differences between untreated and MMA ${ }^{\prime \prime \prime}$ treated cells, ${ }^{*} p \leq 0.05,{ }^{* *} p \leq 0.01,{ }^{* * *} p \leq 0.001, n$ $=3$. 
Figure 4. Effect of MMA'I" on LDH activity. A) Decreased extracellular LDH activity in astrocytes treated with 50-1000 nM MMA'". B) Decreased intracellular LDH activity. Astrocytes were exposed to 25, 50, 125, 250, 500, 1000, 2500 and $5000 \mathrm{nM} \mathrm{MMA} \mathrm{A}^{\text {III }}$ for 24 or $48 \mathrm{~h}$ and then lysed. Released LDH activity was determined using the same LDH-based toxicity assay. Asterisks denote significant differences between not-treated and treated cells, $p \leq 0.05, n=3$.

Figure 5. Reactive oxygen species (ROS) production. A) ROS production after exposure to MMA ${ }^{\text {III }}$ during the first hour. B) ROS production after 2, 4, 6, and $24 \mathrm{~h}$. Asterisks denote significant differences between not-treated and treated cells, $\mathrm{p} \leq 0.05, \mathrm{n}=3$.

Figure 6. Proliferation assay. Astrocytes were exposed to $0,25,50,250,500$ and $1000 \mathrm{nM} \mathrm{MMA}$ III and then assayed for proliferation through BrdU incorporation. All MMA ${ }^{\text {III }}$ concentrations, with exception of $125 \mathrm{nM}$, led to increased astrocytes proliferation after $24 / 48 \mathrm{~h}$ exposure compared to non-exposed cells. Asterisks denote significant differences between untreated and MMA ${ }^{\prime \prime \prime}$ treated cells, ${ }^{*} \mathrm{p} \leq 0.05,{ }^{*} \mathrm{p} \leq 0.01, * * * \mathrm{p} \leq 0.001, \mathrm{n}=3$.

Figure 7. MTS transformation-based metabolic assay. Astrocytes were cultured with 25, 50, 125, 250, 500 and $1000 \mathrm{nM}$ MMA III, metabolic activity was measured after $24 \mathrm{~h}$ through the MTS transformation assay. Asterisks denote significant differences between untreated and MMA ${ }^{\prime \prime \prime}$ treated cells, ${ }^{*} p \leq 0.05,{ }^{* *} p \leq 0.01 . \mathrm{n}=3$.

Figure 8. Pro-inflammatory cytokines gene expression. Cortical rat astrocytes were exposed in vitro to $50,125,250,500$ and $100 \mathrm{nM} \mathrm{MMA}^{\text {II }}$ for $6 \mathrm{~h}$. Total RNA was isolated, reverse-transcribed to cDNA and assayed for IL-1 $\beta$, IL-6, TNF- $\alpha, \mathrm{COX}_{2}$

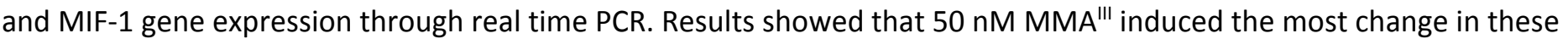
pro-inflammatory cytokines leading to an over-regulation when compared to non-treated astrocytes. TNF- $\alpha$ was overexpressed from 10- to 15-times in cells treated with 50, 125 and $500 \mathrm{nM} \mathrm{MMA}{ }^{\prime \prime \prime}$. Asterisks denote significant differences between untreated and $\mathrm{MMA}^{\prime \prime \prime}$ treated cells, ${ }^{*} \mathrm{p} \leq 0.05, \mathrm{n}=3$.

Figure 9. APP and BACE-1 gene expression. Astrocytes were exposed in vitro to 50, 125, 250, 500 and 1000 nM MMA"I'. cDNA obtained from retro-transcription of total $m R N A$ was assayed for APP and BACE-1 gene expression through real time PCR. Cells exposed to 50 and $500 \mathrm{nM} \mathrm{MMA}$ "II showed a significant over-regulation of APP and BACE-1 gene transcription. Asterisks denote significant differences between untreated and MMA"I treated cells, ${ }^{*} p \leq 0.05,{ }^{* *} p \leq$ $0.01, * * * \mathrm{p} \leq 0.001, \mathrm{n}=3$. 


\section{REFERENCES}

1. Watanabe T, Hirano S (2013) Metabolism of arsenic and its toxicological relevance. Arch Toxicol 87:969-979

2. Leslie EM, Haimeur A, Waalkes MP (2004) Arsenic transport by the human multidrug resistance protein 1 (MRP1/ABCC1). Evidence that a tri-glutathione conjugate is required. J Biol Chem 279:32700-32708

3. Xi S, Sun W, Wang F, Jin Y, Sun G (2009) Transplacental and early life exposure to inorganic arsenic affected development and behavior in offspring rats. Arch Toxicol 83:549-556

4. Jin Y, Xi S, Li X, Lu C, Li G, Xu Y, Qu C, Niu Y, Sun G (2006) Arsenic speciation transported through the placenta from mother mice to their newborn pups. Environ Res 101:349-355

5. Baum L, Chan IH, Cheung SK, Goggins WB, Mok V, Lam L, Leung V, Hui E, Ng C, Woo J, Chiu HF, Zee BC, Cheng W, Chan MH, Szeto S, Lui V, Tsoh J, Bush Al, Lam CW, Kwok T (2010) Serum zinc is decreased in Alzheimer's disease and serum arsenic correlates positively with cognitive ability. Biometals 23:173-179

6. Brinkel J, Khan MMH, Kraemer A (2009) A Systematic Review of Arsenic Exposure and Its Social and Mental Health Effects with Special Reference to Bangladesh. Int J Env Res Pub He 6:1609-1619

7. Piao FY, Ma N, Hiraku Y, Murata M, Oikawa S, Cheng FY, Zhong LF, Yamauchi T, Kawanishi S, Yokoyama K (2005) Oxidative DNA damage in relation to neurotoxicity in the brain of mice exposed to arsenic at environmentally relevant levels. J Occup Health 47:445-449

8. Vahidnia A, van der Voet GB, de Wolff FA (2007) Arsenic neurotoxicity--a review. Hum Exp Toxicol 26:823-832

9. Craft S, Foster TC, Landfield PW, Maier SF, Resnick SM, Yaffe K (2012) Session III: Mechanisms of age-related cognitive change and targets for intervention: inflammatory, oxidative, and metabolic processes. The journals of gerontology Series A, Biological sciences and medical sciences 67:754-759

10. Martinez EJ, Kolb BL, Bell A, Savage DD, Allan AM (2008) Moderate perinatal arsenic exposure alters neuroendocrine markers associated with depression and increases depressive-like behaviors in adult mouse offspring. Neurotoxicology 29:647-655

11. Dani SU (2010) Arsenic for the fool: an exponential connection. The Science of the total environment 408:18421846

12. O'Bryant SE, Edwards M, Menon CV, Gong G, Barber R (2011) Long-Term Low-Level Arsenic Exposure Is Associated with Poorer Neuropsychological Functioning: A Project FRONTIER Study. Int J Env Res Pub He 8:861874

13. Martinez-Finley EJ, Ali AM, Allan AM (2009) Learning deficits in C57BL/6J mice following perinatal arsenic exposure: consequence of lower corticosterone receptor levels? Pharmacol Biochem Behav 94:271-277

14. Rogers JT, Lahiri DK (2004) Metal and inflammatory targets for Alzheimer's disease. Current drug targets 5:535551

15. Fry RC, Navasumrit P, Valiathan C, Svensson JP, Hogan BJ, Luo M, Bhattacharya S, Kandjanapa K, Soontararuks S, Nookabkaew S, Mahidol C, Ruchirawat M, Samson LD (2007) Activation of inflammation/NF-kappaB signaling in infants born to arsenic-exposed mothers. PLoS Genet 3:e207

16. Escudero-Lourdes C, Medeiros MK, Cardenas-Gonzalez MC, Wnek SM, Gandolfi JA (2010) Low level exposure to monomethyl arsonous acid-induced the over-production of inflammation-related cytokines and the activation of cell signals associated with tumor progression in a urothelial cell model. Toxicol Appl Pharmacol 244:162-173

17. Qi Y, Zhang M, Li H, Frank JA, Dai L, Liu H, Zhang Z, Wang C, Chen G (2014) Autophagy inhibition by sustained overproduction of IL6 contributes to arsenic carcinogenesis. Cancer research 74:3740-3752

18. Oberheim NA, Goldman SA, Nedergaard M (2012) Heterogeneity of astrocytic form and function. Methods in molecular biology 814:23-45

19. Farina C, Aloisi F, Meinl E (2007) Astrocytes are active players in cerebral innate immunity. Trends in immunology 28:138-145

20. De Strooper B (2010) Proteases and proteolysis in Alzheimer disease: a multifactorial view on the disease process. Physiological reviews 90:465-494

21. Sastre M, Walter J, Gentleman SM (2008) Interactions between APP secretases and inflammatory mediators. J Neuroinflammation 5:25

22. Avila-Munoz E, Arias C (2014) When astrocytes become harmful: functional and inflammatory responses that contribute to Alzheimer's disease. Ageing research reviews 18:29-40

23. Zhao J, O'Connor T, Vassar R (2011) The contribution of activated astrocytes to Abeta production: implications for Alzheimer's disease pathogenesis. J Neuroinflammation 8:150 
24. Schwartz JP, Wilson DJ (1992) Preparation and characterization of type 1 astrocytes cultured from adult rat cortex, cerebellum, and striatum. Glia 5:75-80

25. Maxwell DP, Wang $Y$, McIntosh L (1999) The alternative oxidase lowers mitochondrial reactive oxygen production in plant cells. Proc Natl Acad Sci U S A 96:8271-8276

26. Schwerdtle T, Walter I, Mackiw I, Hartwig A (2003) Induction of oxidative DNA damage by arsenite and its trivalent and pentavalent methylated metabolites in cultured human cells and isolated DNA. Carcinogenesis 24:967-974

27. Suzuki A, Stern SA, Bozdagi O, Huntley GW, Walker RH, Magistretti PJ, Alberini CM (2011) Astrocyte-neuron lactate transport is required for long-term memory formation. Cell 144:810-823

28. Berridge MV, Tan AS (1992) The protein kinase C inhibitor, calphostin C, inhibits succinate-dependent mitochondrial reduction of MTT by a mechanism that does not involve protein kinase C. Biochem Biophys Res Commun 185:806-811

29. Ferreira ST, Lourenco MV, Oliveira MM, De Felice FG (2015) Soluble amyloid-beta oligomers as synaptotoxins leading to cognitive impairment in Alzheimer's disease. Frontiers in cellular neuroscience 9:191

30. Rodriguez VM, Carrizales L, Jimenez-Capdeville ME, Dufour L, Giordano M (2001) The effects of sodium arsenite exposure on behavioral parameters in the rat. Brain research bulletin 55:301-308

31. Jana K, Jana S, Samanta PK (2006) Effects of chronic exposure to sodium arsenite on hypothalamo-pituitarytesticular activities in adult rats: possible an estrogenic mode of action. Reproductive biology and endocrinology : RB\&E 4:9

32. Nagaraja TN, Desiraju T (1993) Regional alterations in the levels of brain biogenic amines, glutamate, GABA, and GAD activity due to chronic consumption of inorganic arsenic in developing and adult rats. Bulletin of environmental contamination and toxicology 50:100-107

33. Kobayashi H, Yuyama A, Ishihara M, Matsusaka N (1987) Effects of arsenic on cholinergic parameters in brain in vitro. Neuropharmacology 26:1707-1713

34. Zarazua S, Burger S, Delgado JM, Jimenez-Capdeville ME, Schliebs R (2011) Arsenic affects expression and processing of amyloid precursor protein (APP) in primary neuronal cells overexpressing the Swedish mutation of human APP. International journal of developmental neuroscience : the official journal of the International Society for Developmental Neuroscience 29:389-396

35. Kruger K, Straub H, Hirner AV, Hippler J, Binding N, Musshoff U (2009) Effects of monomethylarsonic and monomethylarsonous acid on evoked synaptic potentials in hippocampal slices of adult and young rats. Toxicol Appl Pharmacol 236:115-123

36. Vahidnia A, van der Straaten RJ, Romijn F, van Pelt J, van der Voet GB, de Wolff FA (2007) Arsenic metabolites affect expression of the neurofilament and tau genes: an in-vitro study into the mechanism of arsenic neurotoxicity. Toxicol In Vitro 21:1104-1112

37. Giasson BI, Sampathu DM, Wilson CA, Vogelsberg-Ragaglia V, Mushynski WE, Lee VMY (2002) The environmental toxin arsenite induces tau hyperphosphorylation. Biochemistry-Us 41:15376-15387

38. Lu TH, Tseng TJ, Su CC, Tang FC, Yen CC, Liu YY, Yang CY, Wu CC, Chen KL, Hung DZ, Chen YW (2014) Arsenic induces reactive oxygen species-caused neuronal cell apoptosis through JNK/ERK-mediated mitochondriadependent and GRP 78/CHOP-regulated pathways. Toxicol Lett 224:130-140

39. Escudero-Lourdes C (2016) Toxicity mechanisms of arsenic that are shared with neurodegenerative diseases and cognitive impairment: Role of oxidative stress and inflammatory responses. Neurotoxicology 53:223-235

40. Caito SW, Yu Y, Aschner M (2014) Differential inflammatory response to acrylonitrile in rat primary astrocytes and microglia. Neurotoxicology 42:1-7

41. Akinrinade ID, Memudu AE, Ogundele OM, Ajetunmobi OI (2015) Interplay of glia activation and oxidative stress formation in fluoride and aluminium exposure. Pathophysiology : the official journal of the International Society for Pathophysiology / ISP 22:39-48

42. Niranjan R (2014) The role of inflammatory and oxidative stress mechanisms in the pathogenesis of Parkinson's disease: focus on astrocytes. Molecular neurobiology 49:28-38

43. Koehler Y, Luther EM, Meyer S, Schwerdtle T, Dringen R (2014) Uptake and toxicity of arsenite and arsenate in cultured brain astrocytes. Journal of trace elements in medicine and biology : organ of the Society for Minerals and Trace Elements 28:328-337

44. Castro-Coronel Y, Del Razo LM, Huerta M, Hernandez-Lopez A, Ortega A, Lopez-Bayghen E (2011) Arsenite exposure downregulates EAAT1/GLAST transporter expression in glial cells. Toxicol Sci 122:539-550 
45. Meyer N, Koehler Y, Tulpule K, Dringen R (2013) Arsenate accumulation and arsenate-induced glutathione export in astrocyte-rich primary cultures. Neurochemistry international 62:1012-1019

46. Zhao F, Liao Y, Jin Y, Li G, Lv X, Sun G (2012) Effects of arsenite on glutamate metabolism in primary cultured astrocytes. Toxicol In Vitro 26:24-31

47. Pal A, Prasad R (2014) Recent discoveries on the functions of astrocytes in the copper homeostasis of the brain: a brief update. Neurotoxicity research 26:78-84

48. Hohnholt MC, Geppert M, Luther EM, Petters C, Bulcke F, Dringen R (2013) Handling of iron oxide and silver nanoparticles by astrocytes. Neurochem Res 38:227-239

49. Dringen R (2005) Oxidative and antioxidative potential of brain microglial cells. Antioxid Redox Signal 7:12231233

50. Catanzaro I, Schiera G, Sciandrello G, Barbata G, Caradonna F, Proia P, Di Liegro I (2010) Biological effects of inorganic arsenic on primary cultures of rat astrocytes. International journal of molecular medicine 26:457-462

51. Simeonova PP, Hulderman T, Harki D, Luster MI (2003) Arsenic exposure accelerates atherogenesis in apolipoprotein E(-/-) mice. Environ Health Perspect 111:1744-1748

52. Bunderson M, Brooks DM, Walker DL, Rosenfeld ME, Coffin JD, Beall HD (2004) Arsenic exposure exacerbates atherosclerotic plaque formation and increases nitrotyrosine and leukotriene biosynthesis. Toxicol Appl Pharm 201:32-39

53. Trouba KJ, Germolec DR (2004) Micromolar concentrations of sodium arsenite induce cyclooxygenase-2 expression and stimulate $\mathrm{p} 42 / 44$ mitogen-activated protein kinase phosphorylation in normal human epidermal keratinocytes. Toxicol Sci 79:248-257

54. Lantz RC, Hays AM (2006) Role of oxidative stress in arsenic-induced toxicity. Drug Metab Rev 38:791-804

55. Aguirre-Bañuelos P, Escudero-Lourdes, C., Sanchez-Peña, L.C., Del Razo, L.M., Perez-Urizar, J. (2008) Inorganic arsenic exposure affects pain behavior and inflammatory response in rat. Toxicol Appl Pharmacol 229:937-938

56. Wu J, Liu J, Waalkes MP, Cheng ML, Li L, Li CX, Yang Q (2008) High dietary fat exacerbates arsenic-induced liver fibrosis in mice. Exp Biol Med (Maywood) 233:377-384

57. Gralle M, Ferreira ST (2007) Structure and functions of the human amyloid precursor protein: the whole is more than the sum of its parts. Prog Neurobiol 82:11-32

58. Hardy J, Selkoe DJ (2002) The amyloid hypothesis of Alzheimer's disease: progress and problems on the road to therapeutics. Science 297:353-356

59. Rossner S, Sastre M, Bourne K, Lichtenthaler SF (2006) Transcriptional and translational regulation of BACE1 expression - Implications for Alzheimer's disease. Prog Neurobiol 79:95-111

60. Brugg B, Dubreuil YL, Huber G, Wollman EE, Delhaye-Bouchaud N, Mariani J (1995) Inflammatory processes induce beta-amyloid precursor protein changes in mouse brain. Proc Natl Acad Sci U S A 92:3032-3035

61. Dewji NN, Do C, Bayney RM (1995) Transcriptional activation of Alzheimer's beta-amyloid precursor protein gene by stress. Brain Res Mol Brain Res 33:245-253

62. Rogers JT, Leiter LM, McPhee J, Cahill CM, Zhan SS, Potter H, Nilsson LN (1999) Translation of the alzheimer amyloid precursor protein mRNA is up-regulated by interleukin-1 through 5 '-untranslated region sequences. J Biol Chem 274:6421-6431

63. Ashok A, Rai NK, Tripathi S, Bandyopadhyay S (2015) Exposure to As-, Cd-, and Pb-mixture induces Abeta, amyloidogenic APP processing and cognitive impairments via oxidative stress-dependent neuroinflammation in young rats. Toxicol Sci 143:64-80

64. Jiang T, Cadenas E (2014) Astrocytic metabolic and inflammatory changes as a function of age. Aging cell 13:1059-1067 
Figure 1

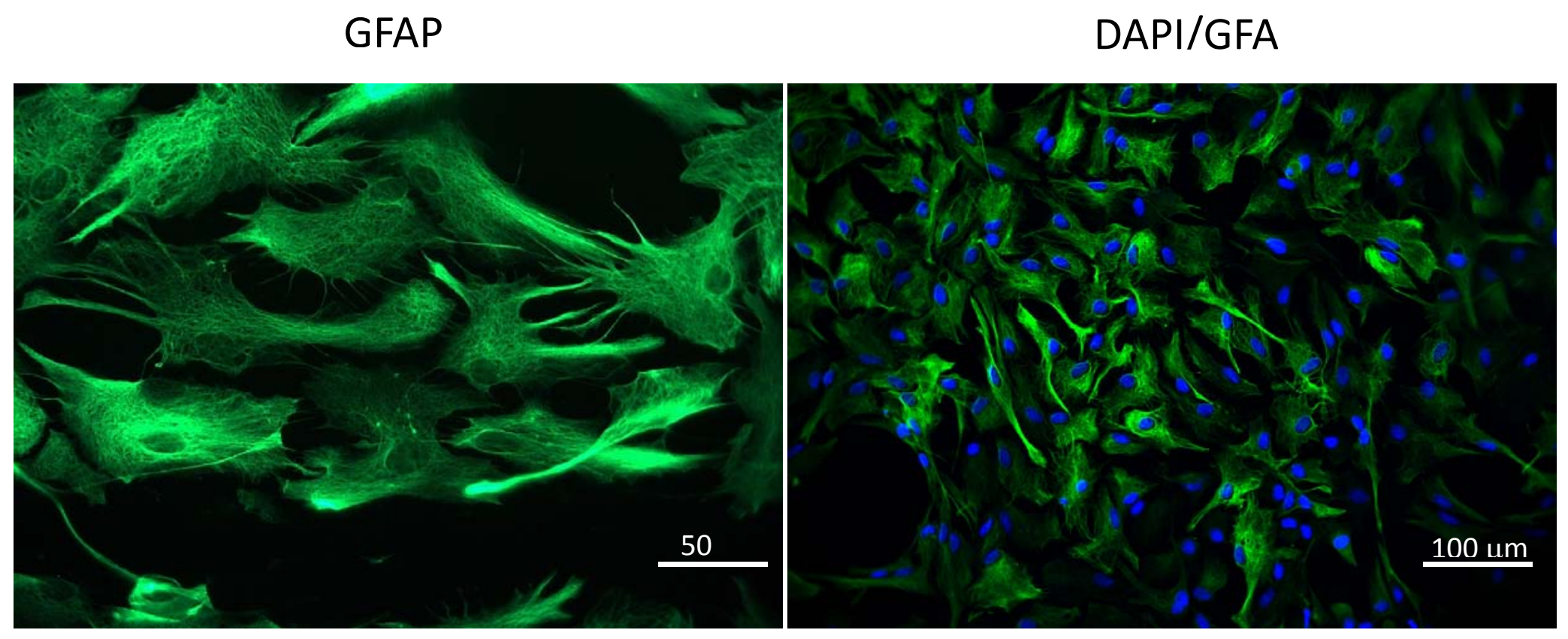


Figure 2
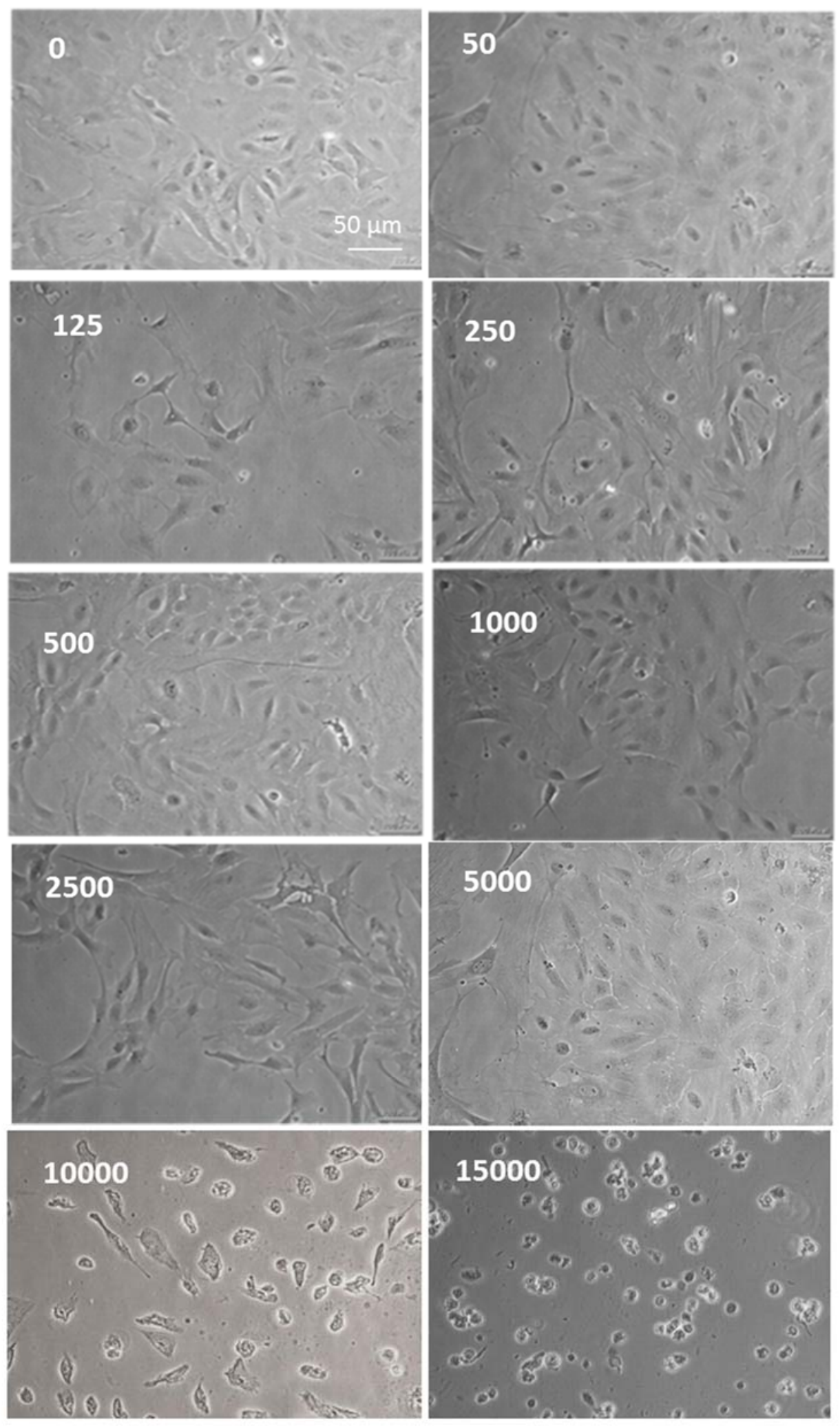
Figure.

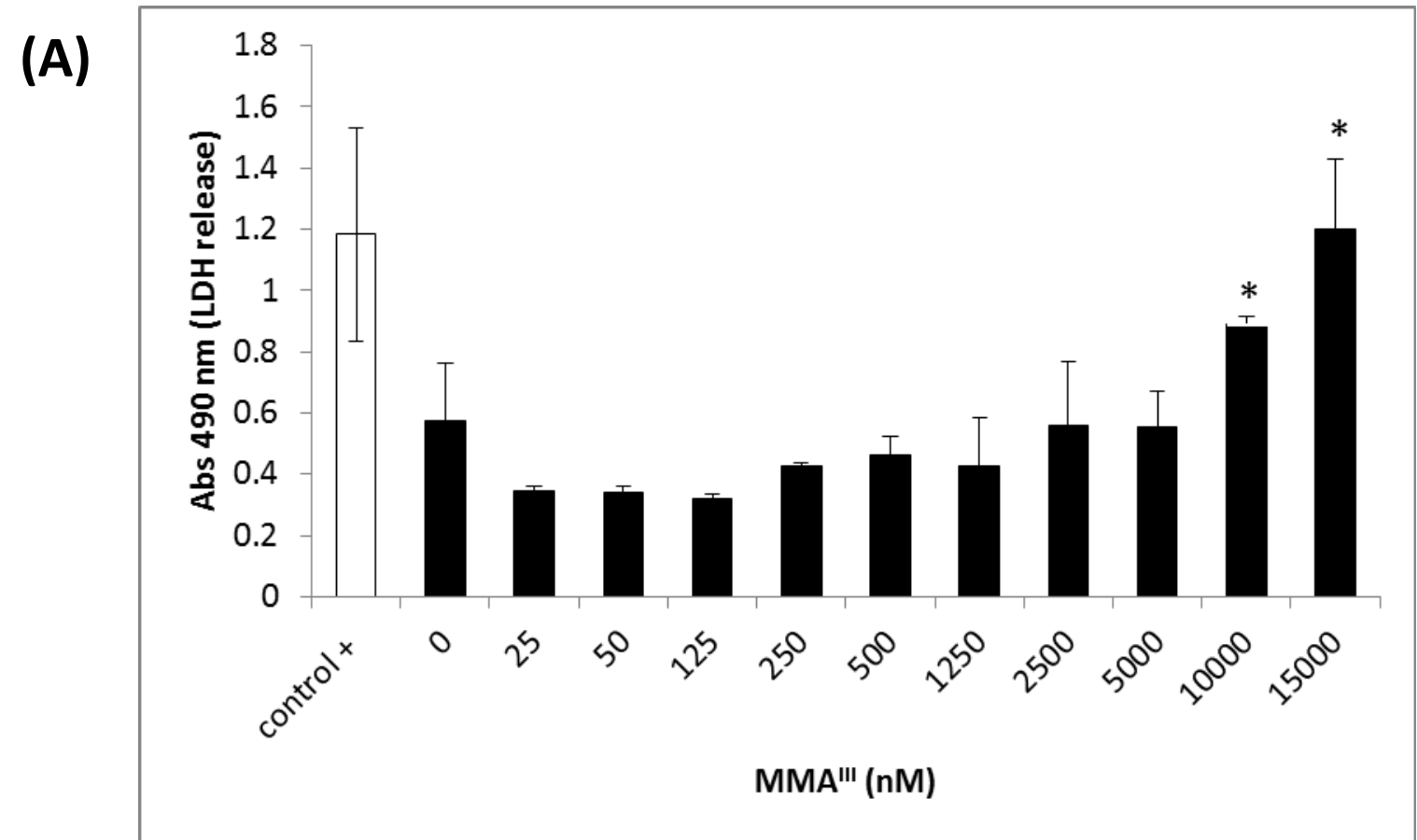

(B)

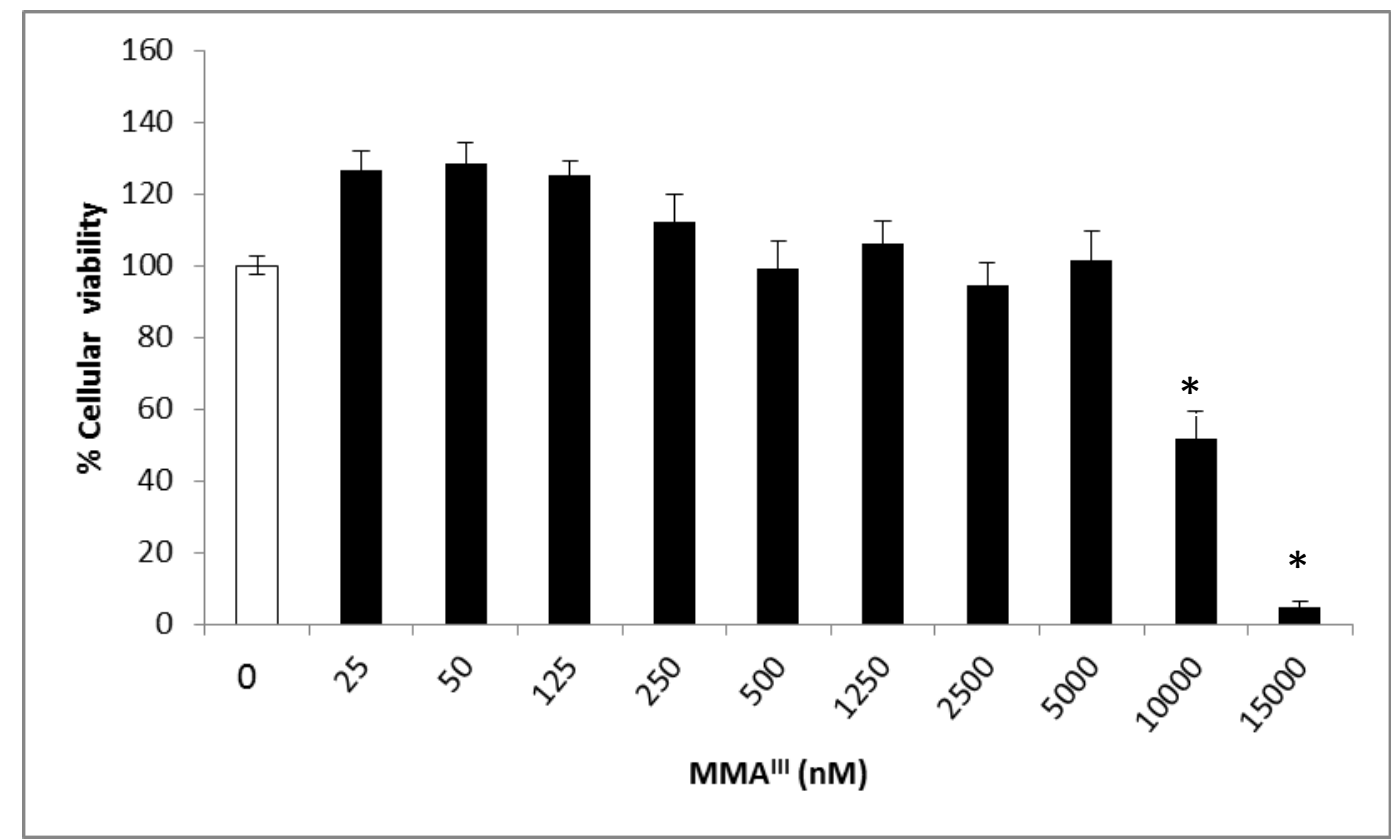


Figure 4

(A)

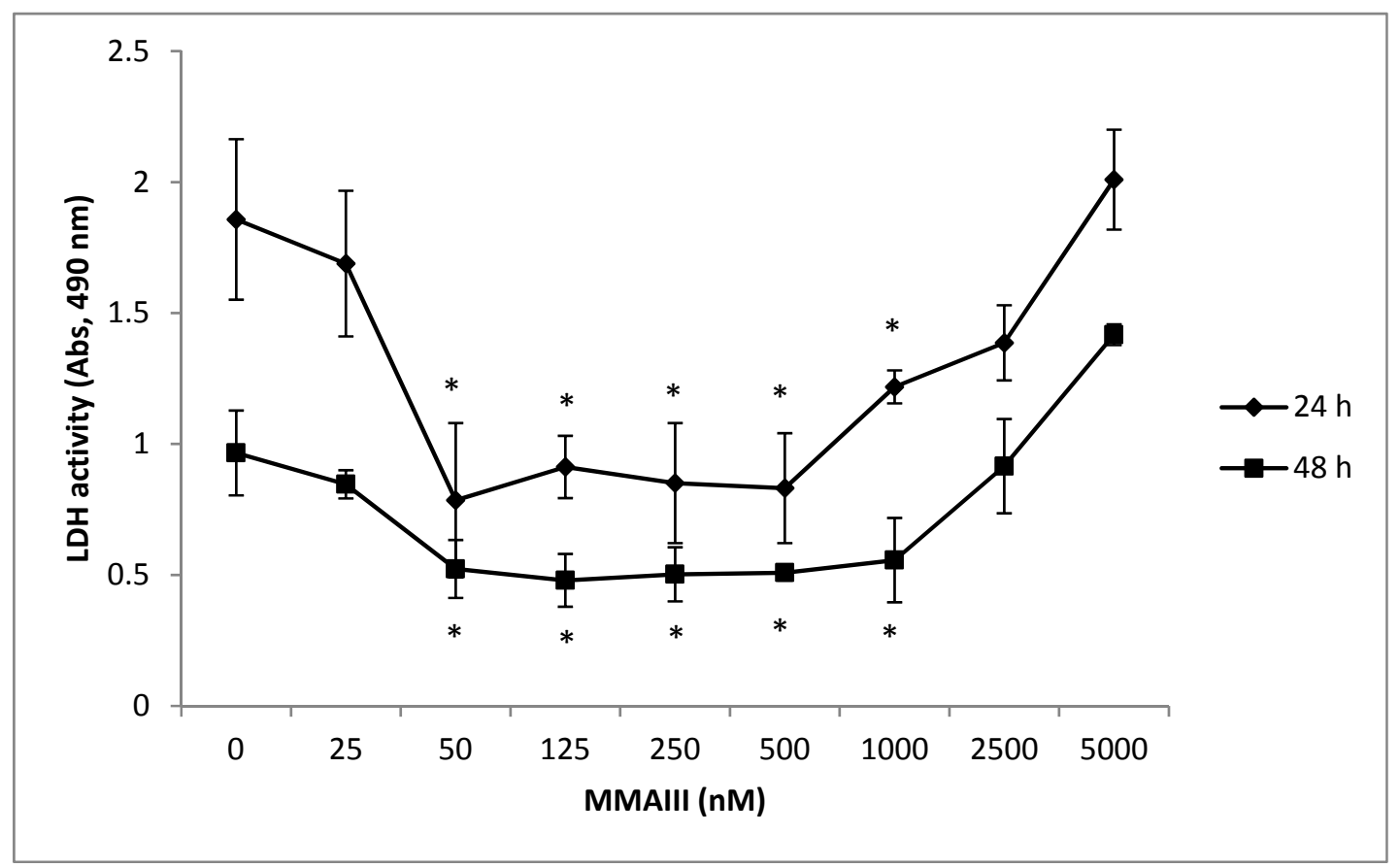

(B)

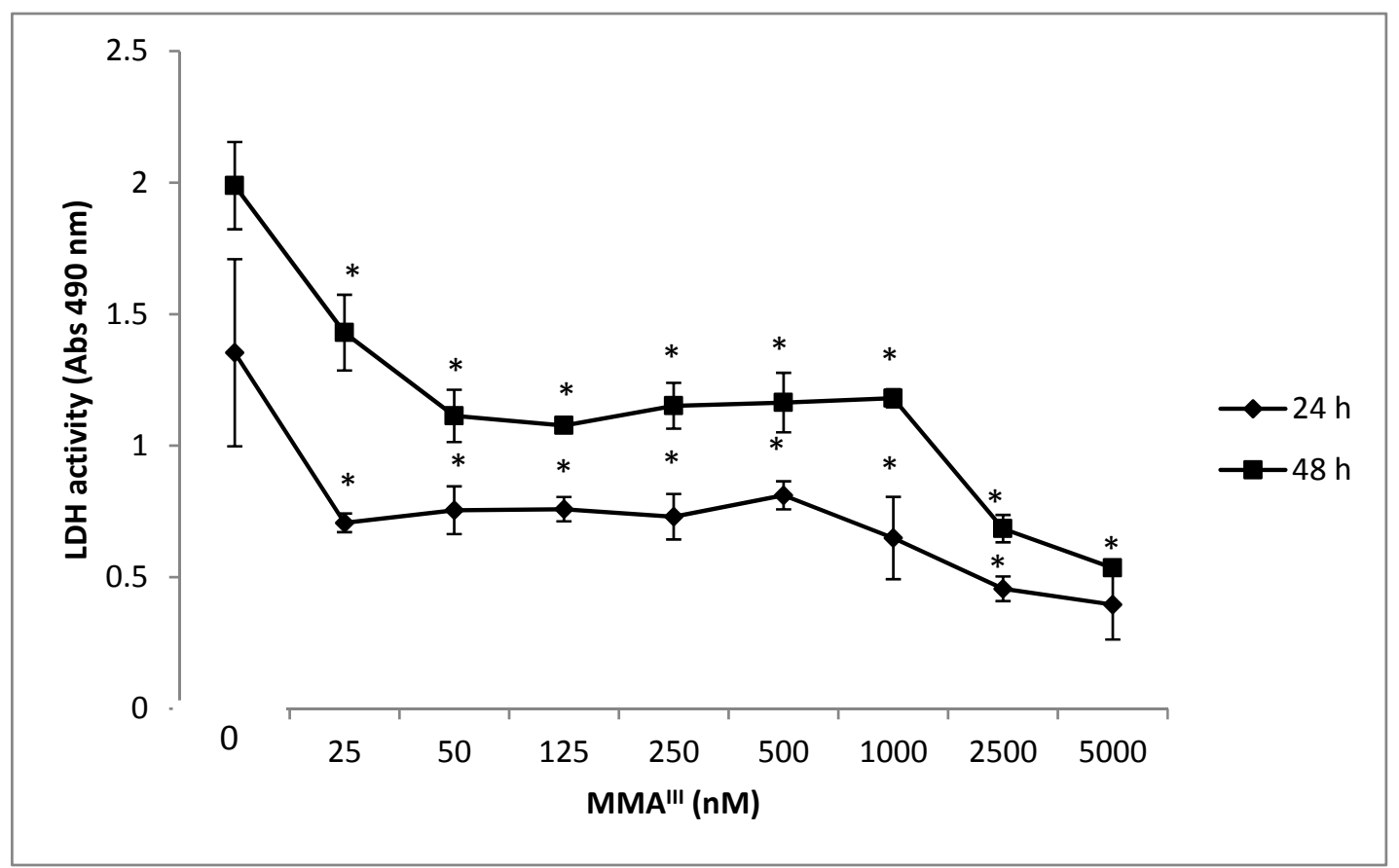


Figure 5.

(A)

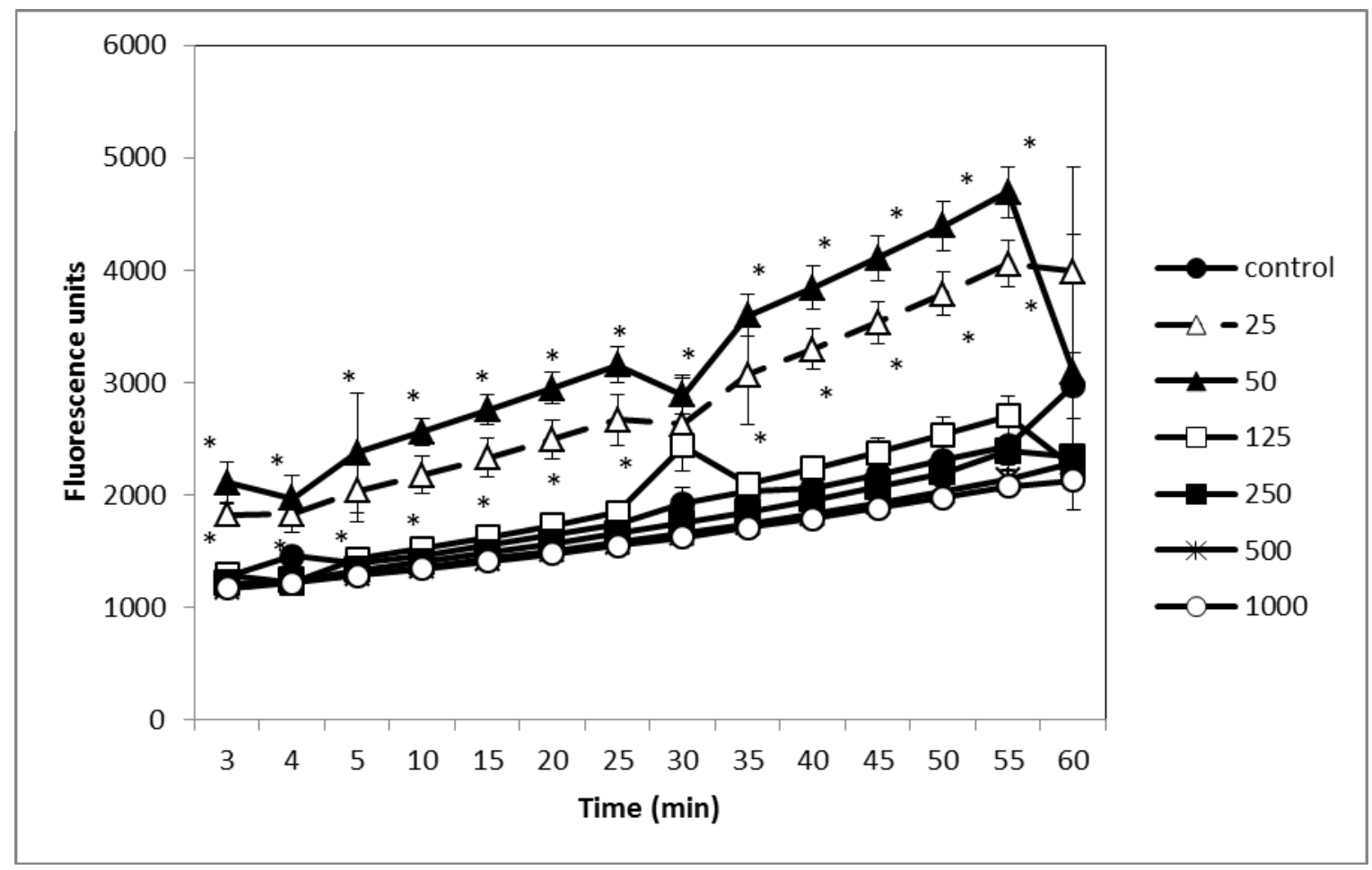

(B)

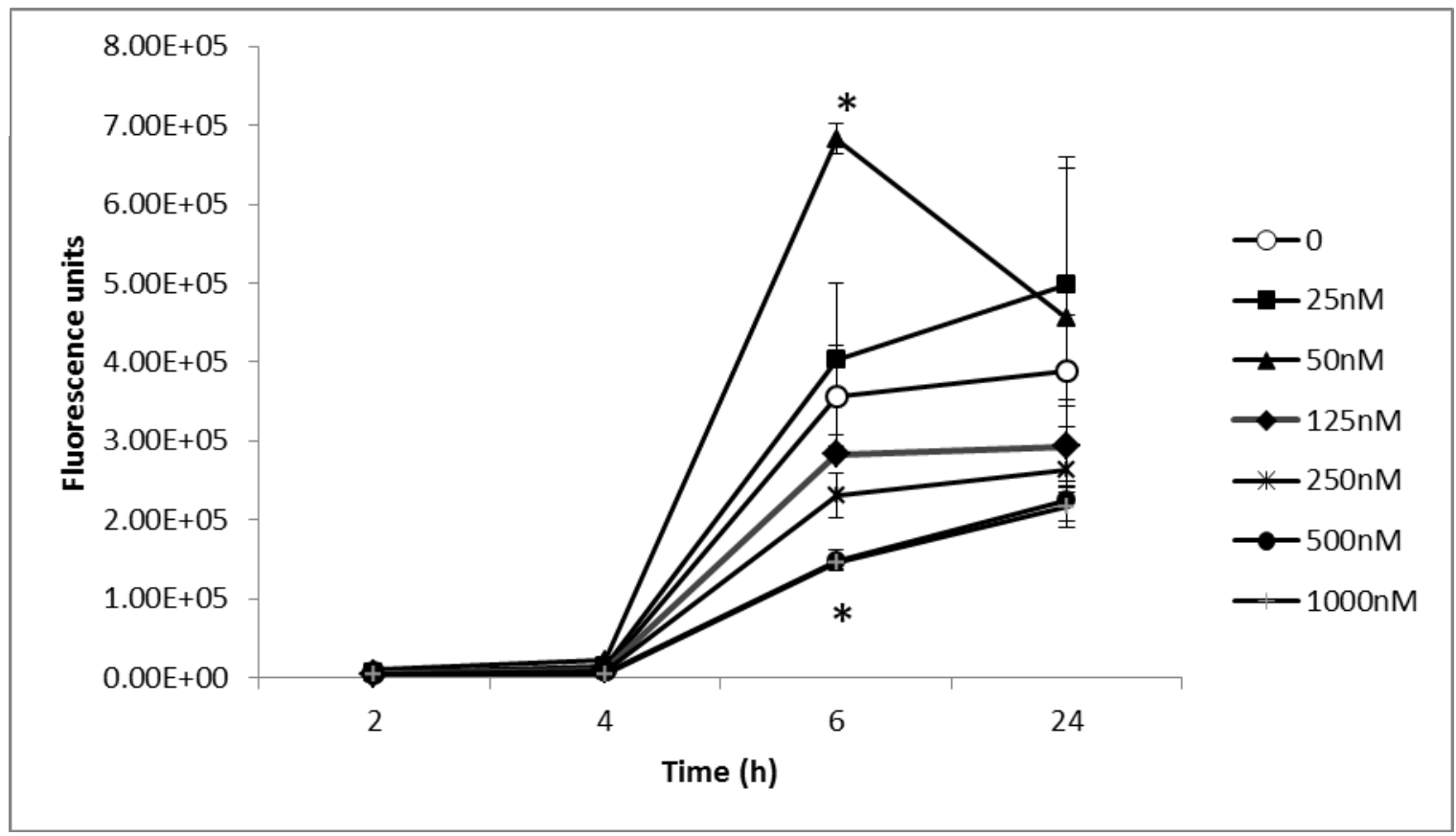


Figure 6.

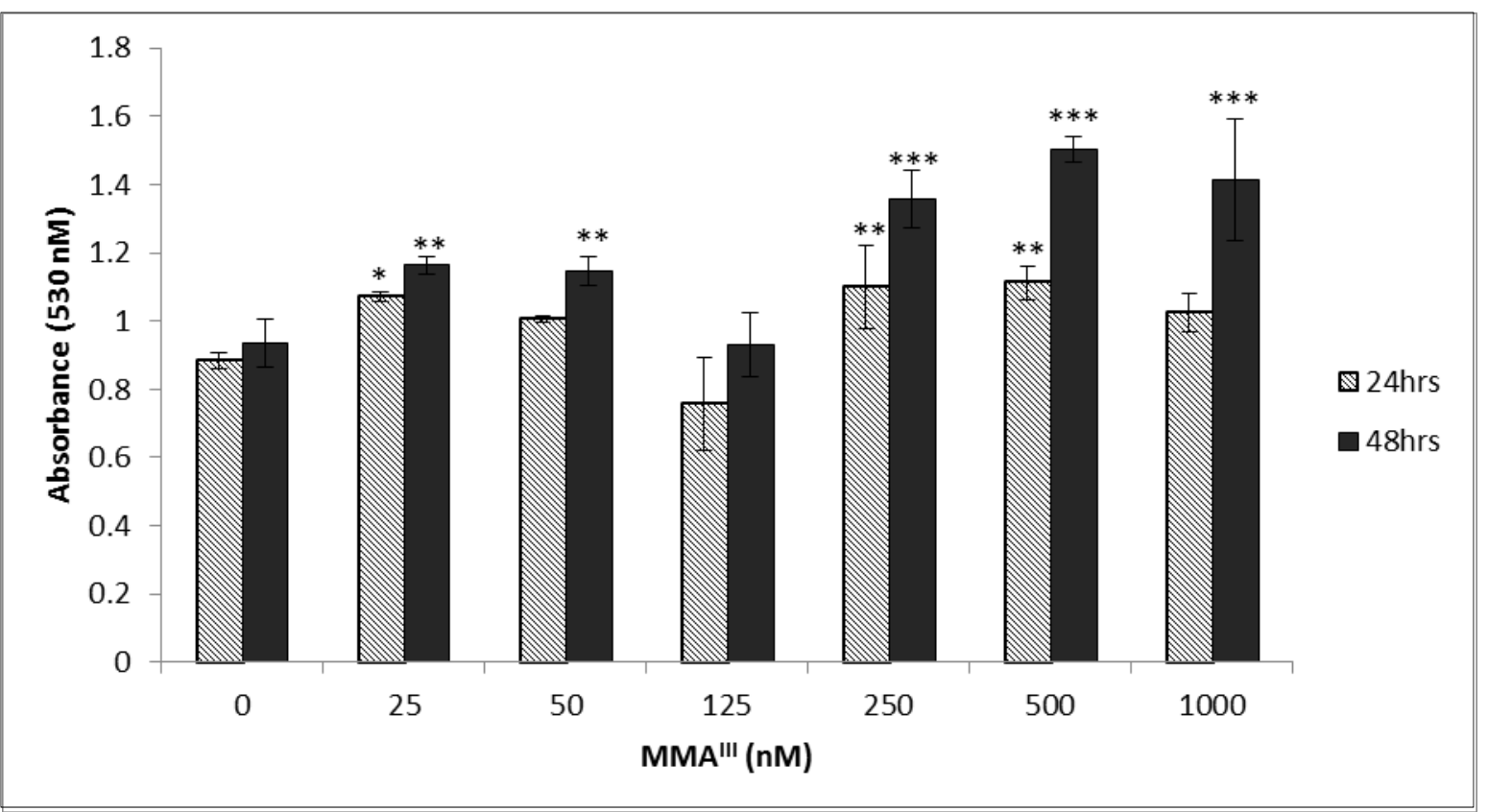


Figure 7.

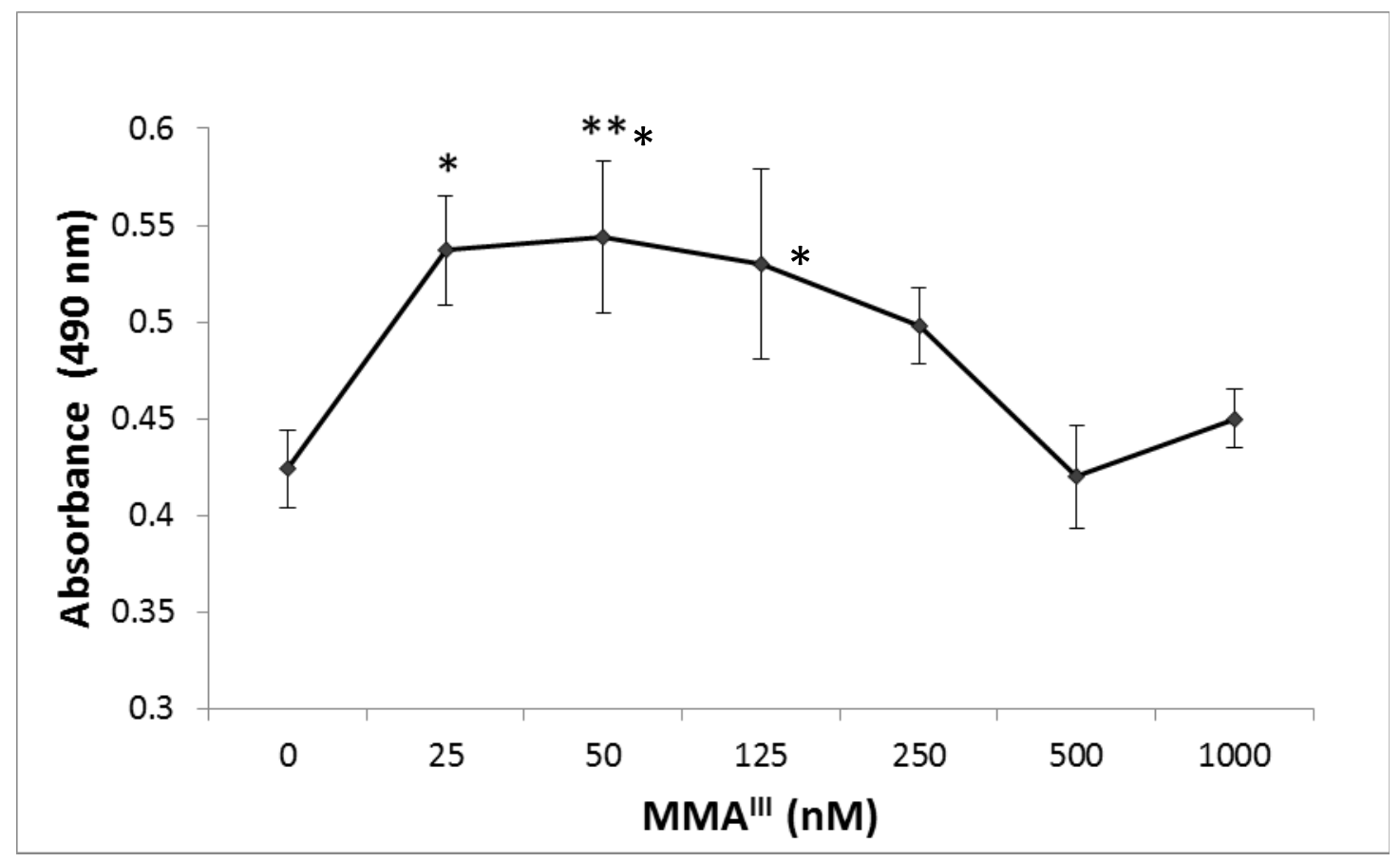


Figure 8.

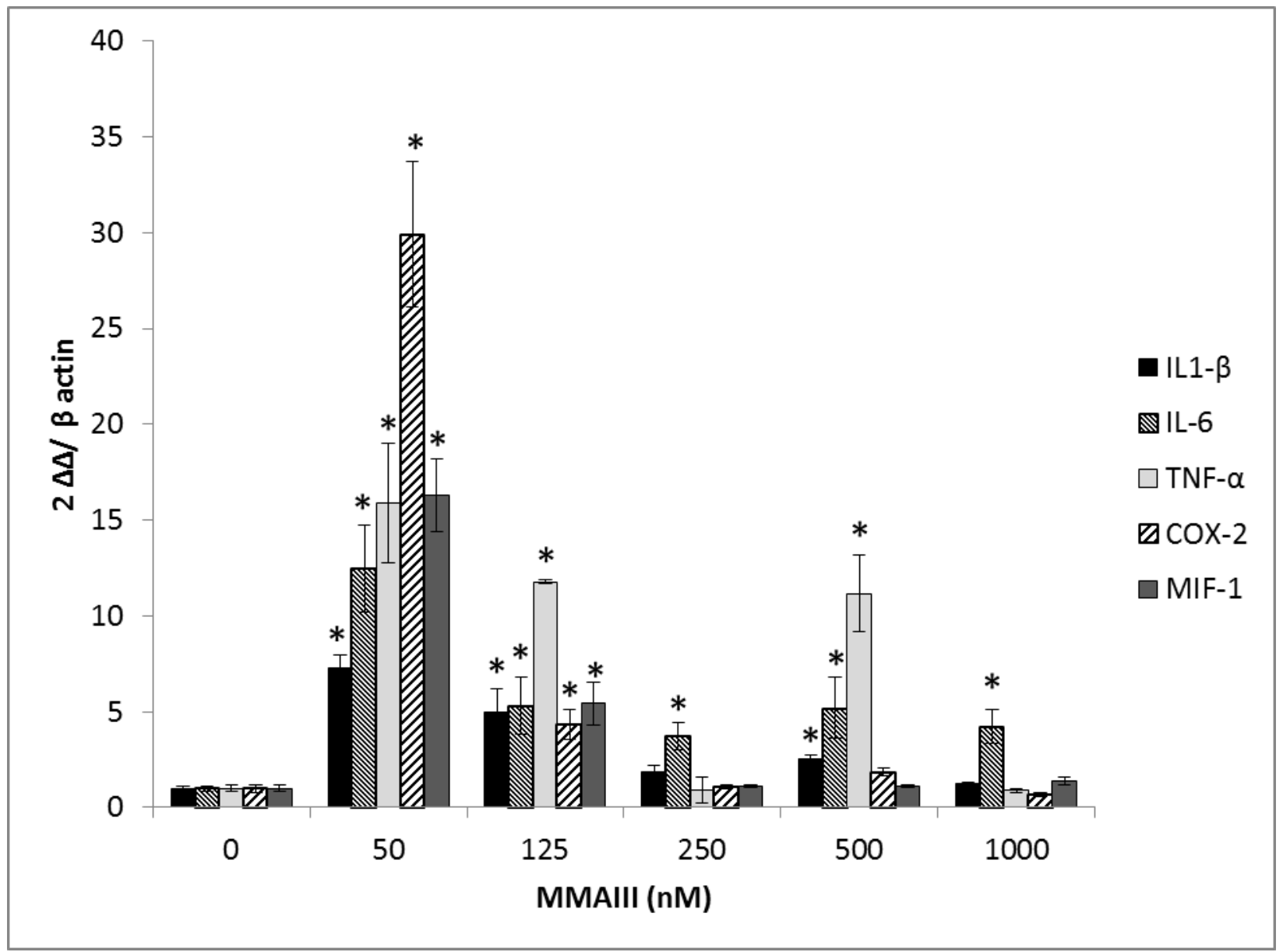


Figure 9.

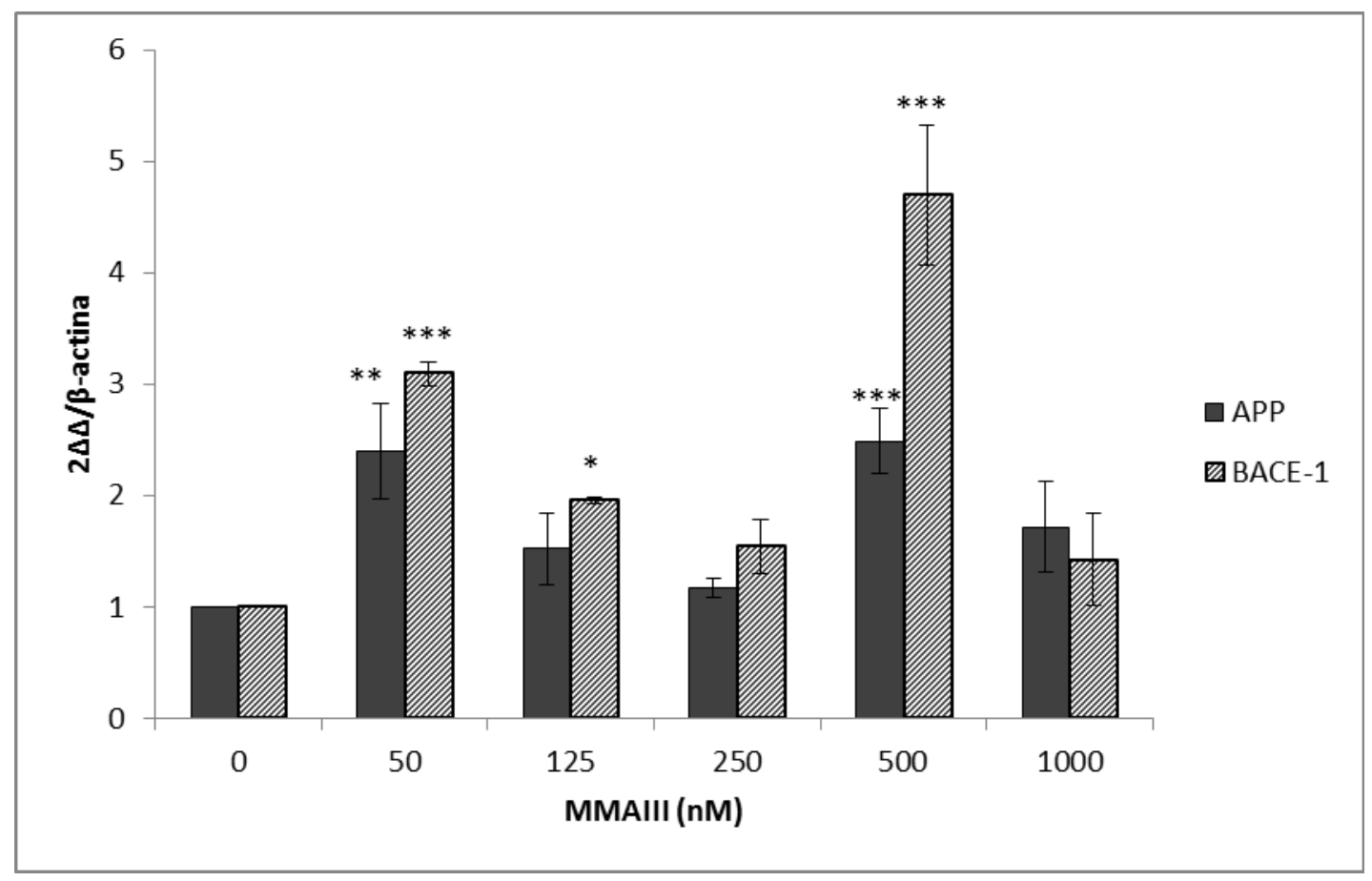

